\title{
A tip of the iceberg-Pseudotanaidae (Tanaidacea) diversity in the North Atlantic
}

\author{
Aleksandra Jakiel $^{1}$ (D) Anna Stępień ${ }^{1} \cdot$ Magdalena Błażewicz $^{1}$ \\ Received: 13 October 2017 / Revised: 20 March 2018 / Accepted: 21 March 2018 / Published online: 3 May 2018 \\ (C) The Author(s) 2018
}

\begin{abstract}
During two IceAGE expeditions, a large collection of Tanaidacea was gathered from the shelf down to the slope (213-2750 $\mathrm{m}$ ) in six areas off Iceland - the Irminger Basin, the Iceland Basin, the Norwegian Sea, the Denmark Strait, the Iceland-Faroe Ridge, and the Norwegian Channel. In this collection, members of the family Pseudotanaidae were most numerous component. We examined 40 samples collected with different gears (e.g., EBS, VVG. GKG), in which 323 pseudotanaid individuals were counted and covered a total depth from 213.9 to $2746.4 \mathrm{~m}$. Morphological identification of the material has revealed the presence of five species: Akanthinotanais cf. longipes, Mystriocentrus biho sp. n. Pseudotanais misericorde sp. n., P. svavarssoni sp. n., and $P$. sigrunis sp. n. The description of the four new species has been presented in the paper and a rank of the subgenus Akanthinotanais is elevated to a genus rank. A large group of morphologically almost identical specimens, similar with $P$. svavarssoni $\mathrm{sp} . \mathrm{n}$. from a wide depth range and from various areas off Iceland was discriminated to species by applying morphometric methods; one distinct species (P. svavarssoni sp. n.) and complex of presumably cryptic species the species was discovered. Based on current data and literature records, similarity among fauna of Pseudotanaidae was assessed with applying Bray-Curtis formula. As results, potential zoogeographic regions in the North Atlantic have been distinguished.
\end{abstract}

Keywords Tanaidacea $\cdot$ Pseudotanaidae $\cdot$ Pseudotanais $\cdot$ Mystriocentrus $\cdot$ Akanthinotanais $\cdot$ New species $\cdot$ Zoogeography IceAGE $\cdot$ Iceland $\cdot$ North Atlantic

\section{Introduction}

Iceland is located at the junction of the Mid-Atlantic Ridge and Greenland-Scotland Ridge (Logemann et al. 2013.) The submarine ridges play an essential role in the oceanic circulation and distribution of water masses, and hence, in the distribution of marine fauna (Asthorsson et al. 2007; Brix and Svavarsson 2010; Schnurr et al. 2014). The Greenland-

This article is registered in ZooBank under: urn:lsid:zoobank.org:pub: F65EDFAB-7032-44B2-9484-06EDD56B87D8.

This article is part of the Topical Collection on Biodiversity of Icelandic Waters by Karin Meißner, Saskia Brix, Ken M. Halanych and Anna Jazdzewska.

Communicated by S. Brix

Aleksandra Jakiel

aleksandrajakiel@wp.pl

1 Department of Invertebrate Zoology and Hydrobiology, University of Łódź, Banacha 12/16, 90-237 Łódź, Poland
Scotland Ridge hampers the interaction between two water masses: the warm water originated in the southern part of North Atlantic, and the polar water from the Arctic Ocean (Logemann et al. 2013; Jochumsen et al. 2016). The warm and saline Atlantic water flows northwards in the nearsurface layer via the Reykjanes Ridge, to continue northernmost as the North Icelandic Irminger Current north-west of Iceland, and over the Iceland-Faroe Ridge east of Iceland (Asthorsson et al. 2007). The cold Arctic water is transported south, partly in the near-surface layer along the Greenland coast (the East Greenland Current), and in part as a bottom current carrying a very cold and dense water from the Nordic Sea down to the south off Iceland (Perkins et al. 1998; Hansen and Osterhus 2000). Since the water masses below the threshold of the Ridge are separated (Jochumsen et al. 2016), biological processes and species composition of faunas in basins located on both sides of the Ridge are thought to be different (Gislason and Astthorsson 2004; Astthorsson et al. 2007).

The specific oceanography of waters surrounding Iceland renders the region an important field laboratory in which to investigate diversity, distribution, and migration of the marine 
fauna. The Icelandic marine Animals Genetic and Ecology (IceAGE) project aimed to understand how underwater physical structures (e.g., submerged ridges) and non-physical barriers (e.g., currents, temperature, salinity) affect the distribution of benthic organisms (Brix et al. 2014). Traditional taxonomic methods as well as modern approaches to biodiversity research (ecological modeling and molecular species discrimination) have been studied for such groups as Isopoda, Tanaidacea, Ophiuroidea, and Mollusca (Brix, 2011; Błażewicz-Paszkowycz et al. 2014; Khodami et al. 2014; Mikkelsen and Todt 2014; Schnurr and Malyutina 2014; Todt and Kocot 2014). Benthic samples collected from an extensive depth range (117-2750 m), at different localities around Iceland, providing an opportunity to test if, and to what extent, topographic and oceanographic barriers (i.e., ridges, currents) influence the distribution, community structure, and diversity of benthic organisms.

The Tanaidacea (Peracarida, Malacostraca) are small marine crustaceans commonly occurring in diverse benthic habitats. As they are brooders and have no planktonic larvae, their mobility is low, and thus their dispersal ability is considered to be limited (Błażewicz-Paszkowycz et al. 2012, 2014). Tanaids may reach high densities (Larsen 2005); under specific environmental conditions (i.e., depth), they were found to be more abundant than amphipods, isopods, or mysids (Bamber 2005). Although the interest in the tanaidacean fauna has been observed to increase during the last decade (e.g., Bamber 2012; Błażewicz-Paszkowycz et al. 2013; Drumm and Bird 2016), the taxon still remains inadequately known. Over 1300 of the species described so far represent some 2-3\% of their estimated diversity (Błażewicz-Paszkowycz et al. 2012).

The IceAGE cruises carried out in 2011 and 2013 (Brix et al. 2013) provided an opportunity to obtain a large collection of tanaidaceans and the family Pseudotanaidae Sieg, 1976 accounted for a substantial part of it (unpublished data of the authors). The family is widespread in the world's ocean, and its members being encountered within a wide depth range: from 0.5 to over $7000 \mathrm{~m}$ (Bird and Holdich 1989a; Błażewicz-Paszkowycz et al., 2012; Pabis et al. 2015). Pseudotanaids have been reported from different habitats, e.g., hard bottom, algae, coral reefs, cold seeps, mud volcanos, and hydrothermal vents (Bird 1999; Błażewicz-Paszkowycz and Bamber 2011; Larsen, 2012; Stępień unpublished data).

So far, 51 species have been described and 21 species have been recorded in the North Atlantic (Fig. 2). Lilljeborg (1864) was the first to report on pseudotanaids, although the family would be established in 1976 by Sieg (1976). Lilljeborg described Pseudotanais forcipatus (Lilljeborg 1864) as Tanais forcipatus from the Swedish coast. Almost 20 years later, Sars (1882) erected the genus Pseudotanais and synonymized the species of Lilljeborg. Moreover, the list of North Atlantic pseudotanaids was supplemented by records of $P$. macrocheles Sars, 1882 and P. lilljeborgi Sars, 1882 from the Norwegian coast (Sars 1882) and P. affinis Hansen, 1887 from the Kara Sea (Hansen 1887). Hansen (1913) added new records of the previously known species and described three new species (P. abyssi Hansen, 1913; P. oculatus Hansen, 1913, and P. longipes Hansen, 1913) from off Iceland and Greenland. The wide distribution of those species in arctic, subarctic, and boreal regions was subsequently reported by numerous authors (e.g., Sars 1896; Greve 1965a, b, c: along the Norwegian coast; Stephensoen 1937: off Greenland, Iceland, and Faroe). The number of pseudotanaid species known in the North Atlantic remained unchanged for the next 60 years until two further species ( $P$. jonesi Sieg, 1977, $P$. similis Sieg, 1977) were described by Sieg from the Bay of Biscay (Sieg 1977). Furthermore Sieg (1977) proposed splitting genus Pseudotanais to two subgenera: Akanthinotanais (A.) and Pseudotanais (P.).

In a series of papers describing results of BIOGAS, GASCOR, and EPI VI programmes, Bird and Holdich (1985, 1989a, b) highlighted the high biodiversity of pseudotanaids in the depth range of $1100-4800 \mathrm{~m}$ in the North Atlantic, mainly west of Great Britain and in the Bay of Biscay. They erected two new genera-Mystriocentrus Bird and Holdich, 1989a and Parapseudotanais Bird and Holdich, 1989b, and described eleven species, namely Mystriocentrus serratus Bird and Holdich, 1989a; Parapseudotanais abyssalis Bird and Holdich, 1989b; Pseudotanais (P.) corollatus Bird and Holdich, 1989a; P. (P.) colonus Bird and Holdich, 1989b; P. $(P)$ denticulatus Bird and Holdich, 1989a; P. (P.) falcicula Bird and Holdich, 1989b; $P$. $(P)$ longispinus Bird and Holdich, 1989a; P. (P.) scalpellum Bird and Holdich, 1989b; P. (P.) spatula Bird and Holdich, 1989a; P. (P.) spicatus Bird and Holdich, 1989b; and P. (P.) vulsella Bird and Holdich, 1989a. Finally, one more species, P. (P.) falcifer Błażewicz-Paszkowycz and Bamber, 2011 from a mud volcano off Norway, was added to the list (BłażewiczPaszkowycz and Bamber 2011).

Our aims in this work were to (1) assess, based on literature data and new records from the IceAGE project, the diversity and distribution of the Pseudotanaidae in the North Atlantic, understood as the area north of $40^{\circ} \mathrm{N}$ (Dinter 2001); (2) describe new species belonging to the family; and (3) based on current data and literature records to assess the similarity among fauna of Pseudotanaidae in various region of The North Atlantic to pinpoint potential zoogeographic regions.

While working on the IceAGE collection, we found a large group of morphologically almost identical specimens from all the basins off Iceland where the samples were collected (the Iceland and Irminger Basins, Denmark Strait, Norwegian Sea, Iceland-Faroe Ridge and the Faroe-Shetland Channel) from a wide depth range. Considering the low mobility of the Tanaidacea (they are tube-building brooders without planktonic stage) and the presence of geographic barriers around Iceland (i.e., submarine ridges, a complex current system), we hypothesize that those morphologically almost identical 
individuals found in different environmental regimes are distinct species. To test the hypothesis, we attempted to discriminate between the species (which are presumably a cryptic species complex) using a morphometric approach.

\section{Study area}

Iceland lies at the junction of the Mid-Atlantic Ridge (MAR) and the Greenland-Scotland Ridge (GSR) (Logemann et al. 2013). As a result of the topography, the oceanic area around Iceland is divided into four basins (Fig. 1). The Iceland and Irminger Basins, located south of the island to the east and west, respectively, are separated by the Reykjanes Ridge, an extension of MAR (Malmberg and Valdimarsson 2003). The two basins are bounded by the Greenland-Iceland Sill (Denmark Strait) to the west and by the Iceland-Faroe Ridge to the East (Malmberg and Valdimarsson 2003). The northern and northeastern basins are the Iceland Sea and the Norwegian Sea, respectively (Malmberg and Valdimarsson 2003), the former being split into two parts by the Kolbeinsey Ridge.

The area south of Iceland is primarily affected by the Atlantic water masses (Fig. 1). The southern and south-eastern shelf is bathed by the South Icelandic Current (SIC) that flows north and north-east and transports the Modified North Atlantic Water
(MNAW). Upon reaching the Faroe-Shetland Ridge, SIC turns to the south-east to flow along the ridge and to open out into the Faroe Current. The south-eastern Icelandic slope (at a depth of $500-1100 \mathrm{~m}$ ) is bathed by the anticlockwise current, made up by the Norwegian Sea Deep Water (NSDW) (Malmberg and Valdimarsson 2003). This water mass, called here the IcelandScotland Overflow Water (ISOW), crosses the Iceland-Faroe Ridge, passes the Iceland Basin, and continues into the Irminger Basin (Meißner et al. 2014).

The deep part (deeper than $1500 \mathrm{~m}$ ) of the Irminger Basin is affected by ISOW as well as by the Denmark Strait Overflow Water (DSOW), which passes though the Denmark Strait and flows south along the Greenland slope) and the Labrador Sea Water (formed in the Labrador Sea) (Malmberg 2004; Meißner et al. 2014) (Fig. 1). The shallower part of the Basin remains under the influence of the Irminger Current (IC), which transports MNAW along the Reykjanes Ridge. IC flows north along the slope (Logemann et al. 2013). Upon reaching the Denmark Strait, IC turns south to flow along the Greenland slope.

The Denmark Strait is, in part, affected by MNAW transported by an IC branch, the North Icelandic-Irminger Current (NIIC) flowing north along the Icelandic shelf edge (Meißner et al. 2014). A cold-water mass [i.e., the Arctic Polar Water (APW, DSOW)] flows along the East Greenland shelf and slope.

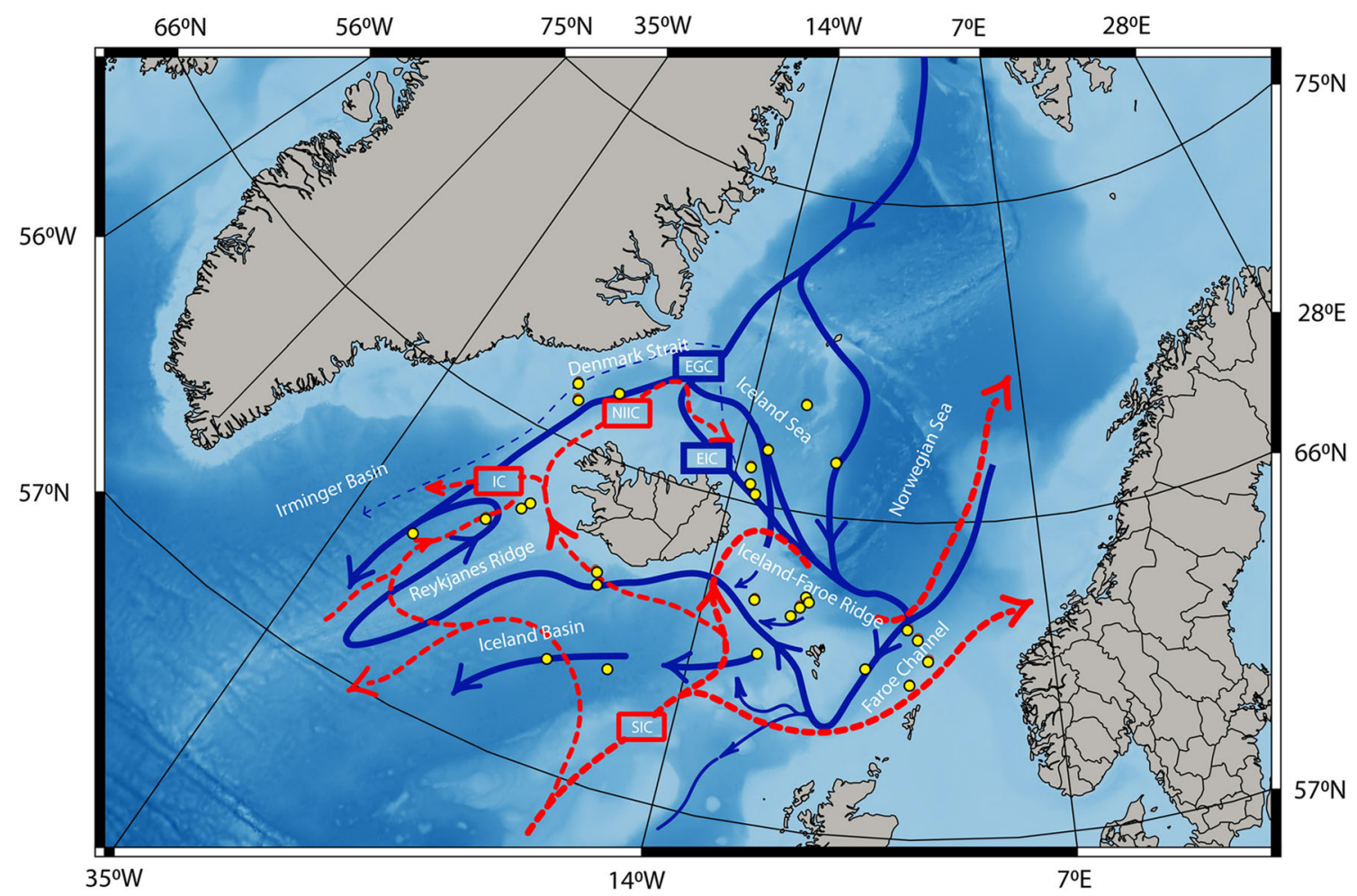

Fig. 1 Study area and location of sampling station (yellow dots) in the $\mathrm{N}$ Atlantic during IceAGE expeditions. Red lines: warm currents (branches of North Atlantic Current); blue lines: cold currents of arctic origin; dashed lines: surface currents; not-dashed lines: deep sea current. $E G C$

East Greenland Curent, EIC East Icelandic Current, IC Irminger Current, NIIC North Icelandic Irminger Current, SIC South Icelandic Current; after Hansen and Osterhus (2000) and Ostmann et al. (2014) 
The north and north-eastern areas experience mixing of several water masses (Meißner et al. 2014). NICC transports the Atlantic water which loses heat here. In addition, shallow areas are affected by the Norwegian Sea Arctic Intermediate Water, deeper parts being influenced by NSDW (Fig. 1). East of the Kolbeinsey Ridge, NIIC and the Arctic Water form the East Icelandic Current (EIC) which bathes the north-eastern continental slope to eventually reach the northern flank of the Iceland-Faroe Ridge. EIC is underlain by the North Icelandic Jet, a cold undercurrent which flows west, within the depth range of 200-1000 m, to cross the Kolbeinsey Ridge and reach the northern part of the Denmark Strait.

\section{Material and methods}

\section{Samples}

This study is based on the pseudotanaid collection obtained during two (2011 and 2013) IceAGE cruises on board the RVs Meteor and Poseidon (Brix et al. 2014). The samples were collected from the shelf down to the slope (213-2750 m) in six areas off Iceland, henceforth referred to as "basins": the Irminger Basin, the Iceland Basin, the Norwegian Sea, the Denmark Strait, the Iceland-Faroe Ridge, and the Norwegian Channel (Fig. 1).

The pseudotanaid material was obtained with different sampling devices: a Van Veen grab (VV), a Shipek grab (SG), a box corer (GKG), and an epibenthic sledge (EBS). It was sieved (500 $\mu \mathrm{m}$ mesh size) using chilled seawater, and preserved in $4 \%$ formaldehyde for morphological research; some individuals were fixed in pre-cooled $96 \%$ undenaturated ethanol for molecular analyses (Riehl et al. 2014). For the purpose of this work, the formaldehyde-treated samples were used only.

A total of 40 samples were examined, which yielded 323 pseudotanaid individuals. Four samples were collected in the Iceland Basin, 6 in the Irminger Basin, 6 in the Denmark Strait, 11 in the Norwegian Sea, 5 in the Norwegian Channel, and 8 off the Iceland-Faroe Ridge (Table 1).

\section{Taxonomic description}

Representative females were dissected using chemically sharpened tungsten needles; appendages were mounted in glycerine on slides. Working drawings were prepared using a microscope equipped with a camera lucida; the publicationquality illustrations were prepared using a digital tablet and Illustrator software (Coleman 2003). The morphological terminology follows that proposed by Błażewicz-Paszkowycz and Bamber (2011). The spatulate setae mentioned by Bird and Holdich $(1989 \mathrm{a}, \mathrm{b})$ are referred to as the sensory setae here.
The material has been deposited in the Universität Hamburg Zoological Museum Center of Natural History (CeNak) (Germany) (Table 2).

\section{Measurements}

We applied a morphometric analysis to strengthen the identification of the most numerous and widely distributed circumIcelandic species of the genus Pseudotanais (described as P. svavarssoni, sp. n. see below). Ovigerous females and neutri individuals (similar in size to ovigerous females) from each basin, with unbroken appendages and a complete blade-like spine, were selected for the analysis (Table 3).

The measurements were made with a camera connected to the microscope (Nikon Eclipse Ci-L) and NIS-Elements View software (www.nikoninstruments.com). The body width and the length of the carapace, pereonites, pleonites, and pleotelson were measured on whole specimens. The length was measured along the axis of symmetry, whereas the width, perpendicular to the axis of symmetry, at the widest spot. As the pseudotanaid pleotelson is usually curved, it was often impossible to observe on a slide; therefore, instead of measuring the total body length, we took three measurements (i.e., the lengths of the carapace, total pereonites, and five pleonites). Thus, the body length is a sum of lengths of all the body segments without the pleotelson.

Appendages were measured (length and width) by measuring their articles on dissected specimens. A total of 173 characters and 29 specimens from four different "populations" (with respect to regions and depth: "population 1" (P1) from the deep ( $2000 \mathrm{~m})$ part of the Norwegian Sea; "population 2" (P2) from the deep $(\sim 1300-1500 \mathrm{~m})$ part of the southern basins: the Iceland and Irminger; "population 3" (P3) from the shallow $(\sim 200 \mathrm{~m})$ part of the southern Irminger Basin; and "population 4" (P4) from the shallow ( 400-600 m) part of the Iceland-Scotland Ridge (the Iceland-Faroe Ridge and the Norwegian Channel) was measured. For the statistical analysis, the following 42 characters/ratios were used:

(1) The combined carapace, pereonite, and pleonite length (CPP)

(2) The CPP to carapace length ratio

(3) The CPP to pereonite-1 length ratio

(4) The CPP to pereonite-2 length ratio

(5) The CPP to pereonite-3 length ratio

(6) Length of CPP to pereonite-4 length

(7) Length of CPP to pereonite-5 length

(8) The CPP to pereonite-6 length ratio

(9) The combined pleonite length to pleon width ratio

(10) The antennule to carapace length ratio

(11) The antennule to antennule article-1 length ratio

(12) The antennule ariticle- 3 to article-2 length ratio

(13) The antenna article-2 to article-2 distal spine length ratio 


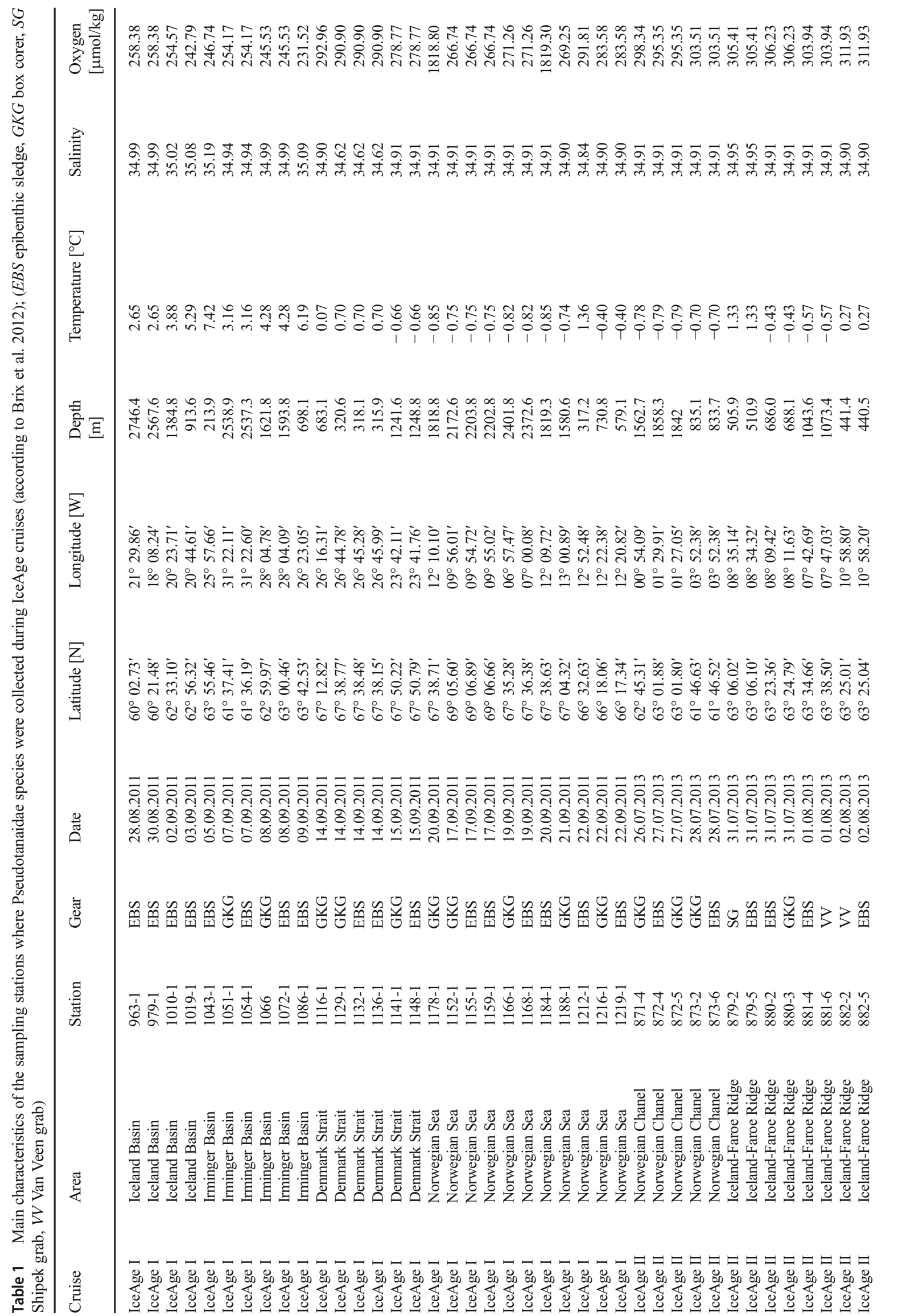









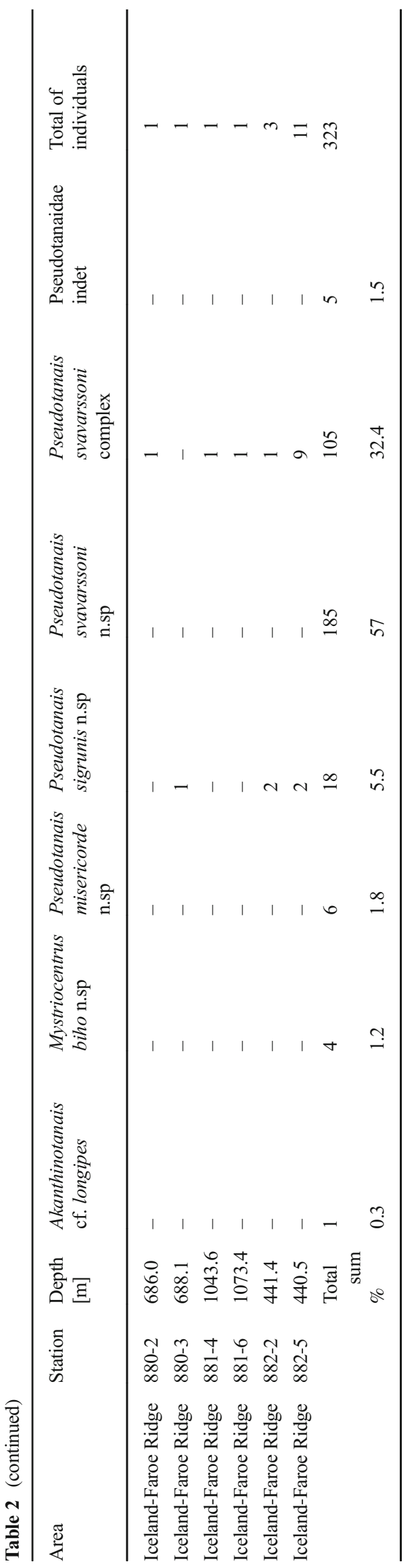

(14) The antenna article-3 to article-3 distal spine length ratio

(15) The cheliped carpus length to width ratio

(16) The cheliped basis to carpus length ratio

(17) The cheliped propodus length to width ratio

(18) The cheliped fixed finger length to propodus length ratio

(19) The pereopod-1 basis length to width ratio

(20) The pereopod-1 propodus to carpus length ratio

(21) The pereopod-1 propodus to dactylus + unguis length ratio

(22) The pereopod-1 unguis to dactylus length ratio

(23) The pereopod-2 propodus to carpus length ratio

(24) The pereopod-2 propodus to dactylus + unguis length ratio

(25) The pereopod-2 propodus to blade-like spine length ratio

(26) The pereopod-3 propodus to carpus length ratio

(27) The pereopod-3 propodus to dactylus + unguis length ratio

(28) The pereopod-3 propodus to blade-like spine length ratio

(29) The pereopod-4 propodus to carpus length ratio

(30) The pereopod-4 propodus to dactylus + unguis length ratio

(31) The pereopod-4 propodus to blade-like spine length ratio

(32) The pereopod-4 propodus to carpus distal seta length ratio

(33) The pereopod-5 propodus to carpus length ratio

(34) The pereopod-5 propodus to blade-like spine length ratio

(35) The pereopod-4 propodus to carpus distal seta length ratio

(36) The pereopod-6 propodus to carpus length ratio

(37) The pereopod-6 propodus to dactylus + unguis length ratio

(38) The pereopod-6 propodus to blade-like spine length ratio

(39) The pereopod-6 propodus to carpus distal seta length ratio

(40) The pleonite combined length to uropod basis and endopod combined length ratio

(41) The uropod basis length to width ratio

(42) The uropod exopod to endopod length ratio

\section{Statistical analysis}

The Kruskal-Wallis test with multiple post-hoc comparison (Statistica 10 software) was used to find out which of the ratios or characters determined significantly differentiate between the four "populations"studied. The characters and ratios identified by the test were used further to perform the principal component analysis (PCA) and analysis of similarity (ANOSIM). PCA is an ordination method in which samples (specimens here) regarded as points in a multi-dimensional space are projected onto a best fit plane (Clarke and Gorley 2006). Prior to the analysis, the data were normalized.

ANOSIM (Clarke and Gorley 2006) was conducted to test for the degree and significance of differences between a priori determined groups ("populations") of specimens: ANOSIM calculates a test statistic (Global R) which equals 1 if all individuals within a population are more similar to each other than to any individual in another population, and 0 if there is no difference between populations (Clarke and Gorley 2006). The relevant dissimilarity matrix was constructed using the normalized Euclidean distance. 


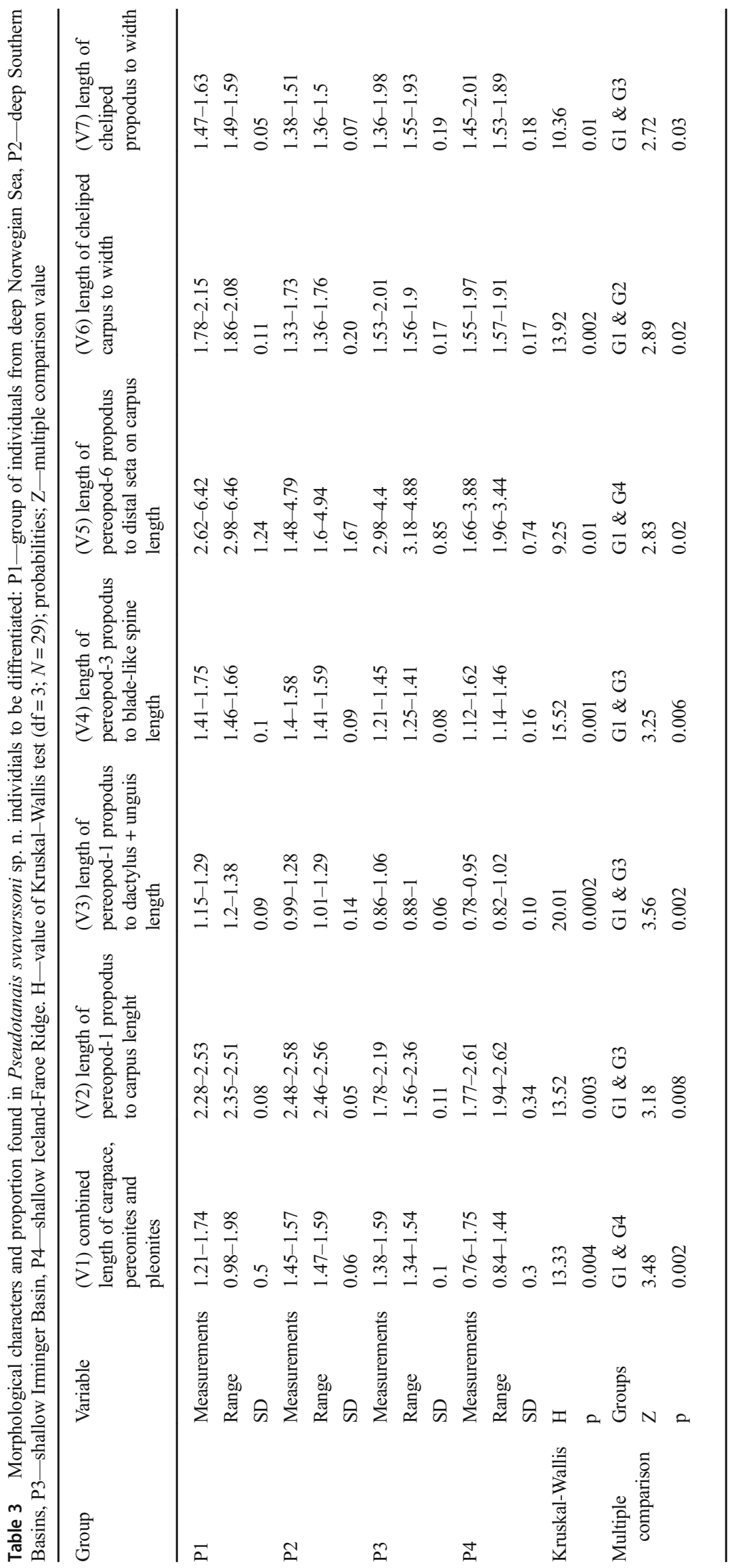


Fig. 2 Distribution of the

Pseudotanaidae species in the

North Atlantic based on literature (present study not included): Bird and Holdich (1989a, b);

Błażewicz-Paszkowycz and

Bamber (2011); Bruce et al.

(1963); [Dahl] in Sieg (1977);

[Deboutteville (1960),

Deboutteville et al. (1954)] in

Sieg (1983); [Fee, Hatch] in Sieg

(1977); Greve (1965a, b, c);

Hansen (1887, 1913); Holdich

and Bird (1986); Holdich and

Jones (1983); Just (1970);

Kruuse, Ryder, Wandel in Hansen

(1913); Liljeborg (1864); Sars

(1882, 1896); Stephensen (1937);

Sieg (1977); [Vanhöffen, Kruuse,

Ryder, Horring, Sars] in Hansen

(1913); [Vanhöffen, R. Horring,

H.J. Hansen, Sars, A.M. Norman,

Stappers, Th. Scott] in Hansen

(1913); see Table 4

Fig. 2 (continued)

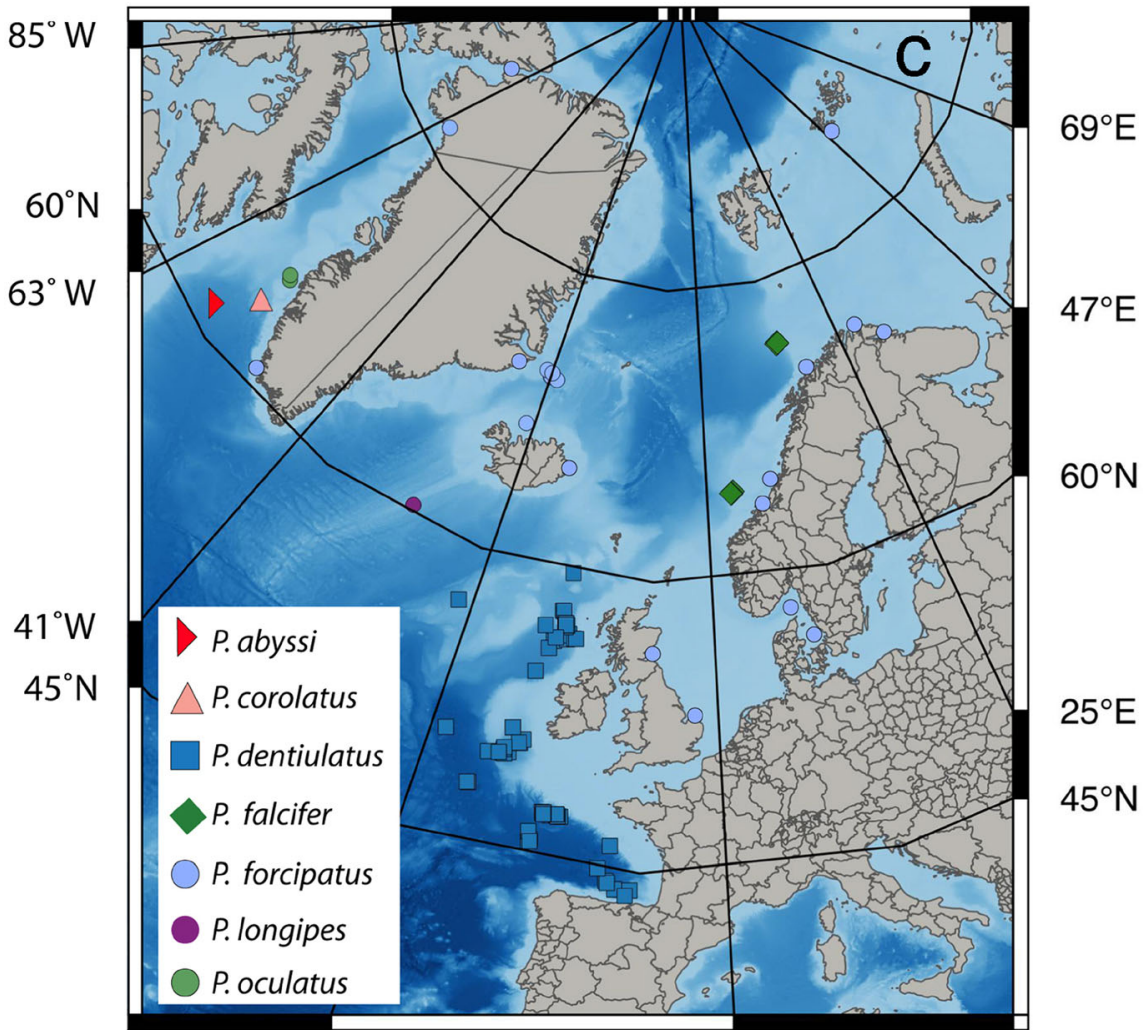

$19^{\circ} \mathrm{W}$

$3^{\circ} \mathrm{E}$

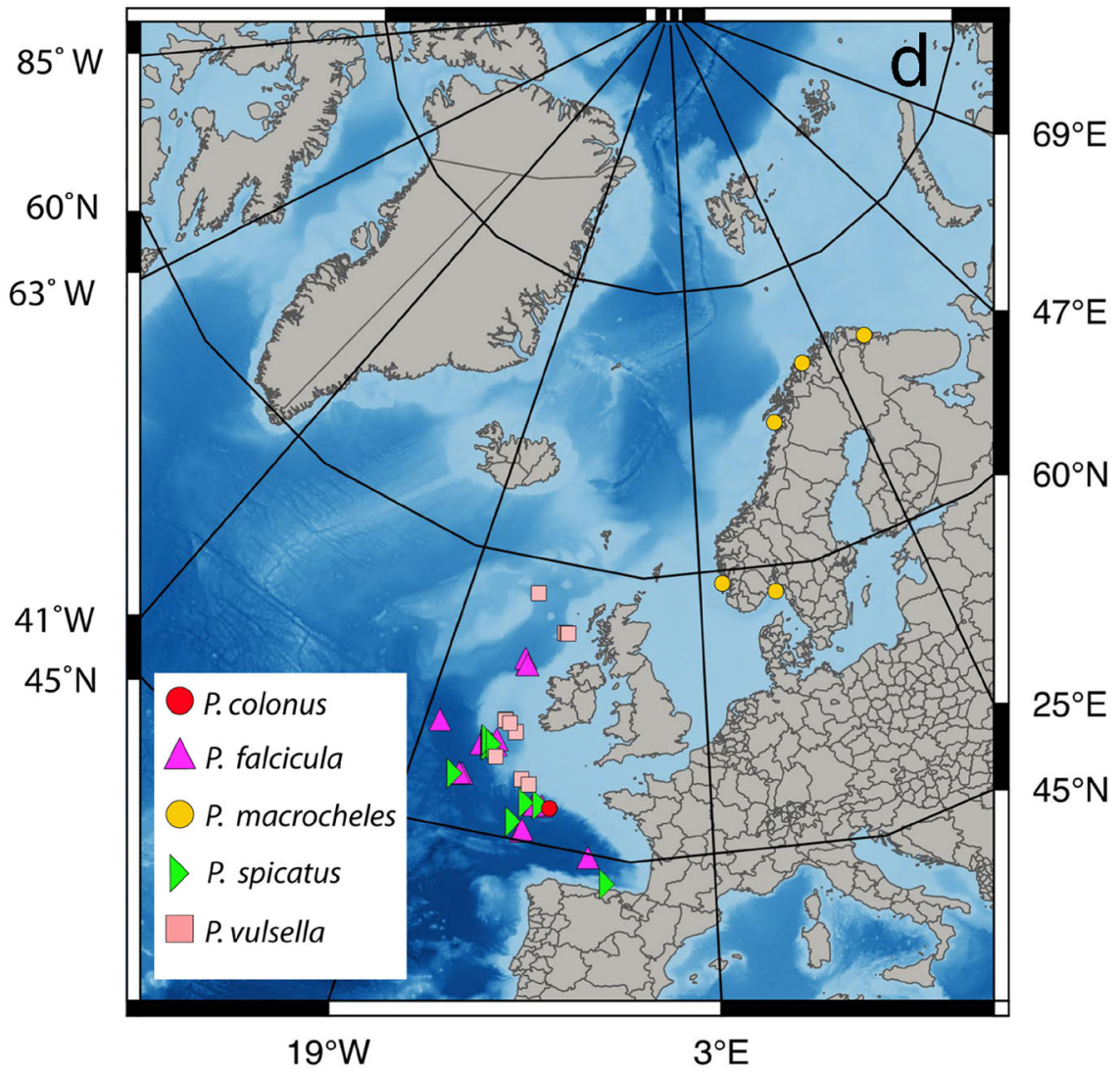


Fig. 3 Plot of principal component analysis based on seven morphometric characters (V1-7) of P. svavarssoni sp. $\mathrm{n}$. and $P$. svavarssoni complex. List of character in Table 3

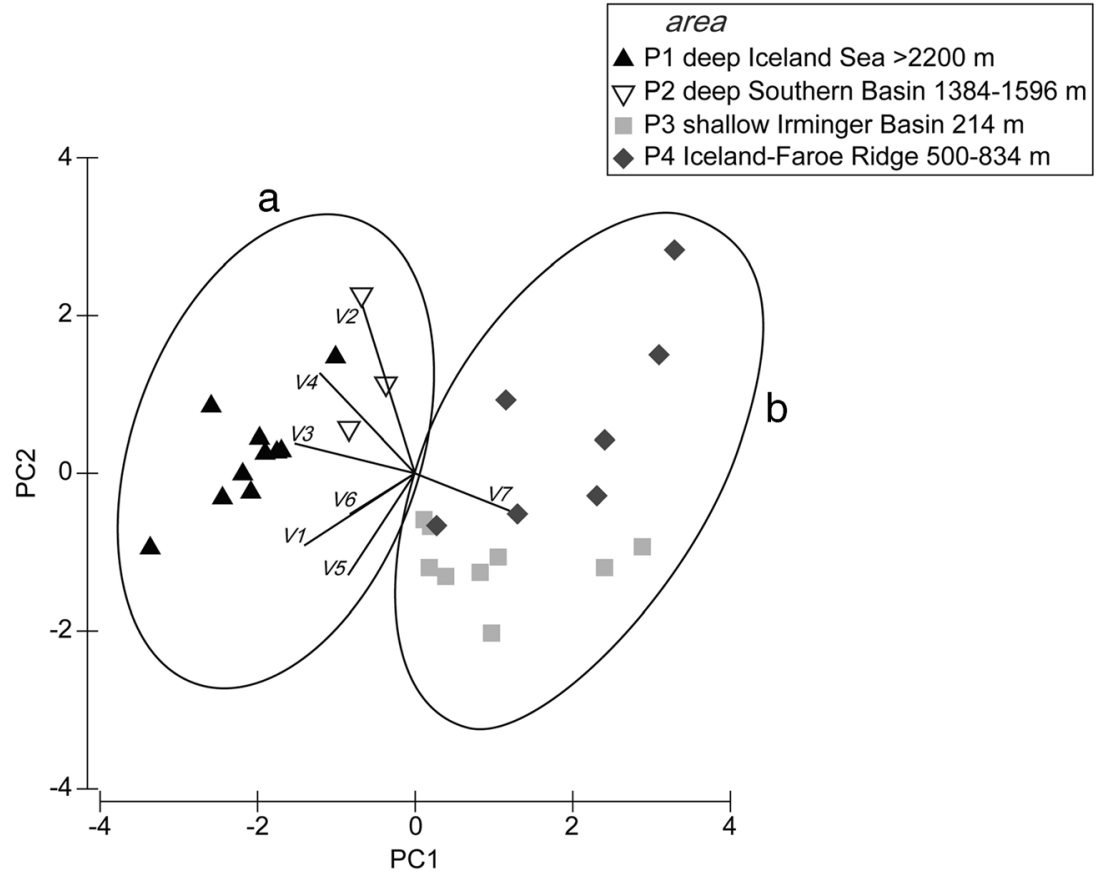

Similarities between the North Atlantic sites of pseudotanaids were determined in multivariate analysis using the group-average cluster and derived from the presence/absence-based Bray-Curtis similarity coefficient. In case of the species with particularly wide distribution (e.g., P. affinis, P. lilljeborgi, P. forcipatus), the records from a type locality and/or vicinity of the type localities only were included to analysis. In this approach, all potentially erroneous records and the records of possible cryptic species were excluded. PCA, ANOSIM, and group-average clustering were run using the PRIMER v. 6 package (Clarke and Gorley 2006).

\section{Results}

\section{Species composition}

The morphological approach adopted in this study allowed to identify five pseudotanaid species representing three genera: Akanthinotanais Sieg, 1977, Mystriocentrus Bird and Holdich, 1989b, and Pseudotanais Sars, 1882. The third genus yielded three species (including two new for science), Akanthinotanais and Mystriocentrus being represented by one species each.

\section{Species discrimination}

PCA run with the seven morphometric characters initially identified as significantly discriminating (Table 3 ) was applied to the most numerous pseudotanaid species (Pseudotanais svavarssoni sp. n.) and resulted in the first five PCs accounting for $90 \%$ of the total variation. Most of the variability in the seven characters is captured in the $2 \mathrm{D}$ projection plotted in
Fig. 3. The first and the second $\mathrm{PC}$ axes (PC1 and $\mathrm{PC} 2)$ explain 44 and $16 \%$ of the total variance, respectively. $\mathrm{PC} 1$ axis
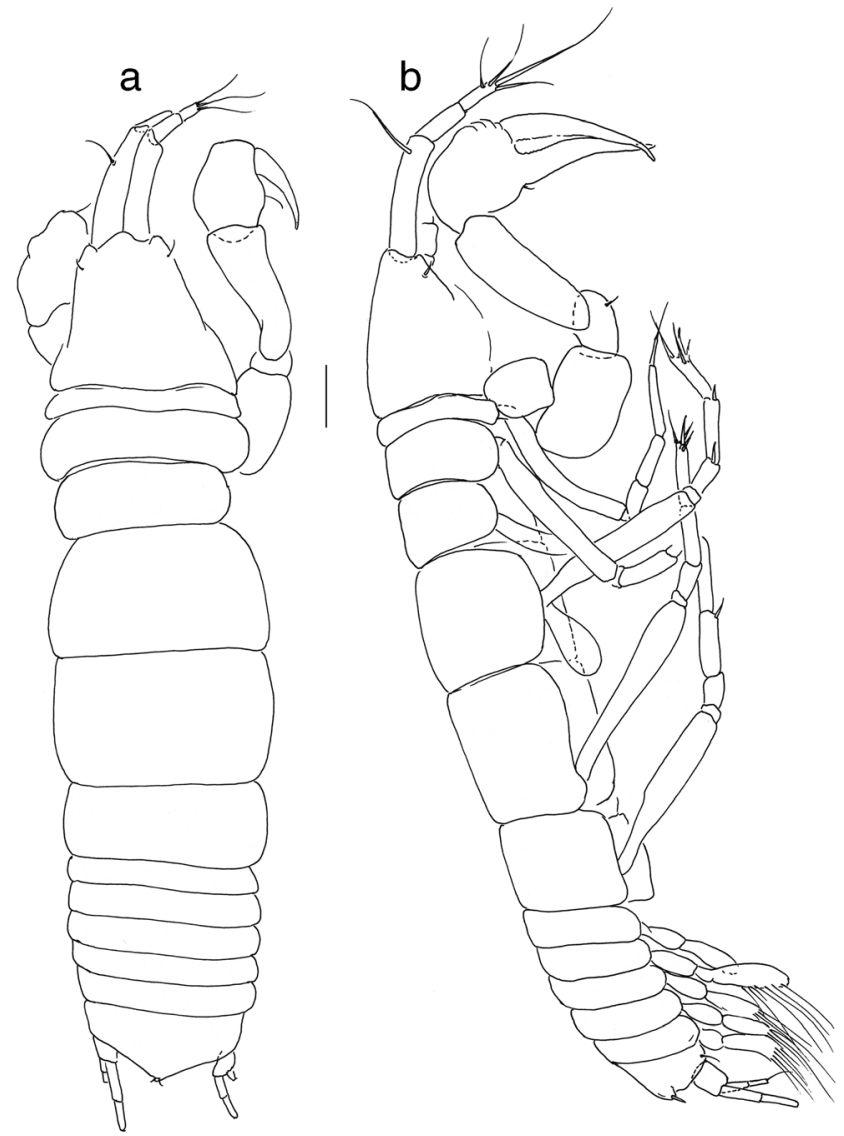

Fig. 4 Mystriocentrus biho sp. n., female with oostegites (cat no...). a Dorsal view. b Lateral view. Scale: $0.1 \mathrm{~mm}$ 
Fig. 5 Mystriocentrus biho sp. n., preparatory female, paratype (cat no...). a Antennule. b Antenna. c Labrum. d Left mandible. e Right mandible. f Maxillule. $g$ Maxilliped. h Details of maxilliped palp. Scale: $0.1 \mathrm{~mm}$ for $\mathbf{a}-\mathbf{b}$ and $0.01 \mathrm{~mm}$ for $\mathbf{c}-\mathbf{h}$



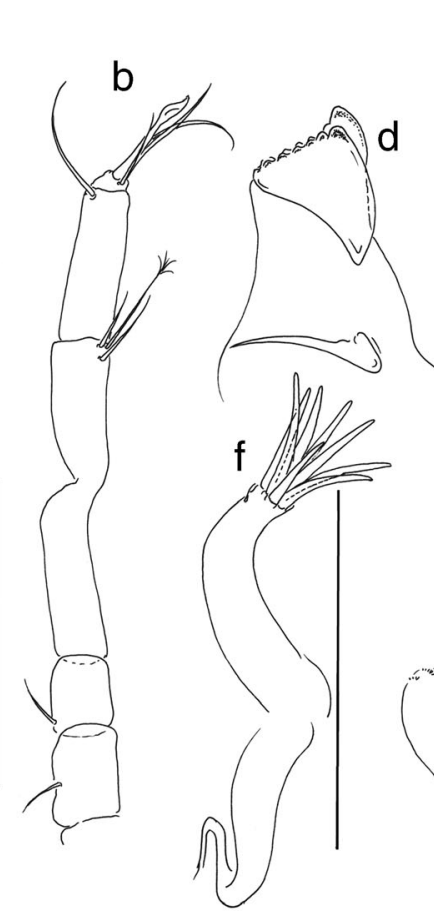

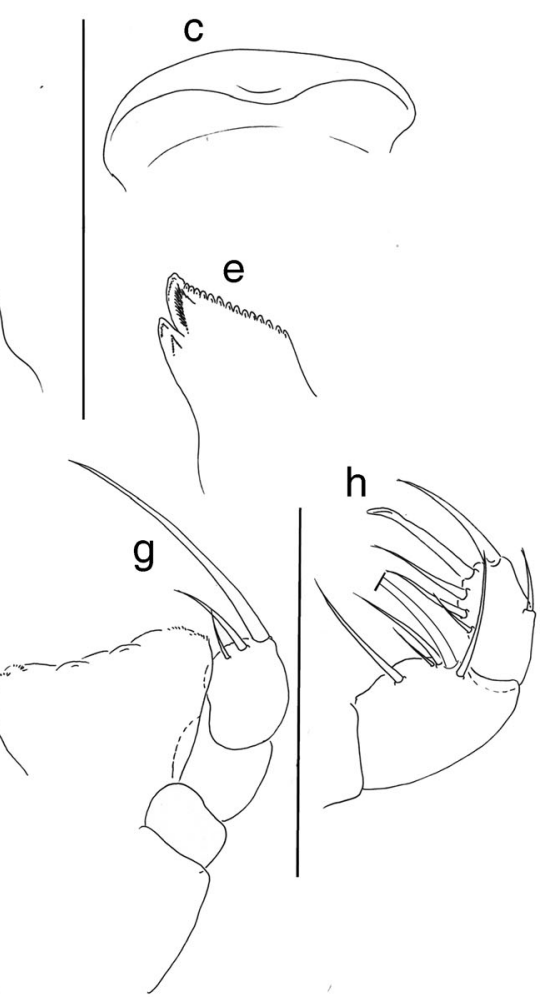

separated the specimens examined into two groups (A, B) (Fig. 3). The group A consists of those individuals collected from deeper stations $(>1300 \mathrm{~m}$ ) in the Irminger and Iceland Basins as well as the Norwegian Sea, the group B includes specimens found in shallow-water $(<800 \mathrm{~m})$ samples from the Iceland-Scotland Ridge and the Irminger Basin.

Most variables decreased along the PC1 axis (from left to right), the highest values being attained by characters V4, V1, and V2 (Fig. 3, Table 3). An opposite trend (values increasing along PC1) was shown by the V7 (chelae propodus length to width ratio only).

ANOSIM showed significant morphometric differences (Global $R=0.68, p=0.1 \%$ ) between populations from the regions examined. The highest differences were found between the specimens representing "population 1" (deeper stations in the Norwegian Sea) and "population 3" (shallow stations in the Irminger Basin) (Global $R=0.88, p=0.1 \%$ ) as well as between specimens from "population 1 " and "population 4" (shallow stations in ISR) (Global $R=0.83$; $p=0.1 \%$ ). Significant, relatively high differences were also detected between specimens from "population 2" (deeper stations in the Irminger and Iceland Basins) and "population 3" (Global $R=0.74 ; p=0.5 \%$ ) and between specimens from "population 1" and "population 2" (Global $R=0.63, p=$ $1 \%)$. Differences in morphometry between specimens from "population 3" and "population 4" were weaker (Global $R=0.33)$, but still significant $(p=0.7 \%)$.
The morphometric analysis confirmed morphological differences between groups of individuals collected from different regions and depths. The differences, although present, are detectable only with careful measurement of the seven characters identified; therefore, the results indicated the presence of at least two (but possibly four) cryptic species. Moreover, as the strongest differences were observed between specimens from deep stations in the Norwegian Sea and all the other individuals (Table 3), we decided to choose a holotype for the newly described species (P. svavarssoni sp. n., see below) from those stations. As the differences between the other three sets of specimens (shallow stations in ISR, and Irminger Basin, deeper stations in the Irminger and Iceland Basins) were less pronounced, we decided to retain them as the "svavarssoni" complex until genetic data would lend reasonable support to the presence of distinct species.

\section{Taxonomic descriptions}

Family Pseudotanaidae Sieg 1976

Genus: Mystriocentrus Bird and Holdich, 1989a

Diagnosis (amended after Bird and Holdich, 1989b): pereonite-2 similar in length or longer than pereonites 1 and 3 ; antenna articles 1 and 2 with simple setae, and with thickened seta on article- 6 (terminal); molar process acuminate and simple; maxilliped endites fused, palp article-4 with thickened 
Fig. 6 Mystriocentrus biho sp. n., preparatory female. a Cheliped. b Pereopod-1. c Pereopod-2. d Pereopod-3. e Pereopod-4. f Pereopod-5. g Pereopod-6. h Uropod. i Pleopod. Scale: $0.1 \mathrm{~mm}$

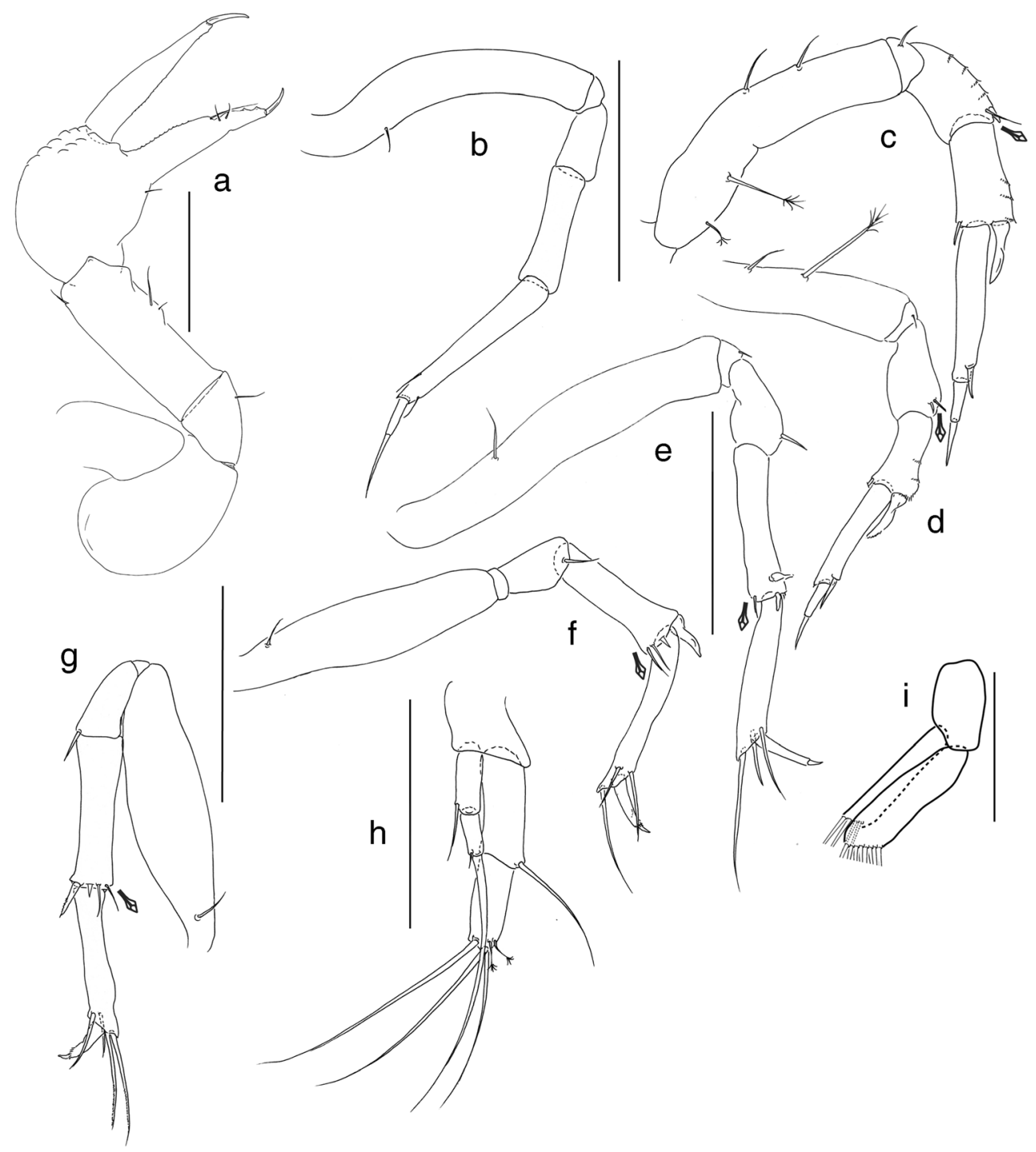

seta; cheliped propodus almost as long as wide (1-1.2 times as long as wide), and small folds in distodorsal corner; chela forcipate, with serrate inner margin; pereopods 2-6 with blade-like spine on carpus.

Type species: M. serratus Bird and Holdich, 1989a

Species included: M. serratus Bird and Holdich, 1989b; $M$. biho, sp. n.

Remarks: Until examination of the Pseudotanaids from IceAGE collection (present studies), the Mystriocentrus was monotypic genus. Most of the diagnostic character for genus given as by Bird and Holdich 1989a, b (e.g., relatively long pereonite- 2 , thickened seta on antennule article- 6 and maxilliped palp article-4, forcipate seta with serrate incisive margins and folds in distodorsal corner, and blade like spines on carpus of pereopods 2-6 well define this genus so far. Observed in type species "spatulate setae" on merus and carpus (through which the genus received its name Bird and Holdich 1989a: 277) might not be so robust generic character, although still valid for species identification (see Remarks page 14).

Mystriocentrus biho sp. n. Registered in ZooBank under: urn:lsid:zoobank.org:act:0AED0F58-63D5-4524A857-FE6EC2883162 Figs. 4, 5, and 6

Material examined: Holotype: Ovigerous female, $\mathrm{ZMH}$ K-54850, St 1054-1, 61 $36.82^{\prime}$ N $31^{\circ} 22.26^{\prime} \mathrm{W}-61^{\circ} 36.98^{\prime}$ N $31^{\circ} 22.18^{\prime} \mathrm{W}$, depth 2545.7-2536.8 m, EBS, 07 Sep 2011.

Paratypes: neutrum (dissected), ZMH K-54852, St. 1019$1,62^{\circ} 56.46^{\prime} \mathrm{N} 20^{\circ} 44.06^{\prime} \mathrm{W}-62^{\circ} 56,52^{\prime} \mathrm{N} 20^{\circ} 43,77^{\prime} \mathrm{W}$, depth 916.1-909.4 m, EBS, 03 Sep 2011.

Two neutri, ZMH K-54851, St 1054-1, 61 ${ }^{\circ} 36.82^{\prime} \mathrm{N} 31^{\circ}$ $22.26^{\prime} \mathrm{W}-61^{\circ} 36.98^{\prime} \mathrm{N} 31^{\circ} 22.18^{\prime} \mathrm{W}$, depth 2545.7 $-2536.8 \mathrm{~m}$, EBS, 07 Sep 2011. 
Fig. 7 Distribution of the Pseudotanaidae species collected during IceAGE cruises. Distribution of Pseudotanais affinis, $P$. corollatus, $P$.

denticulatus, and P. lilljeborgi as in the Fig. 2
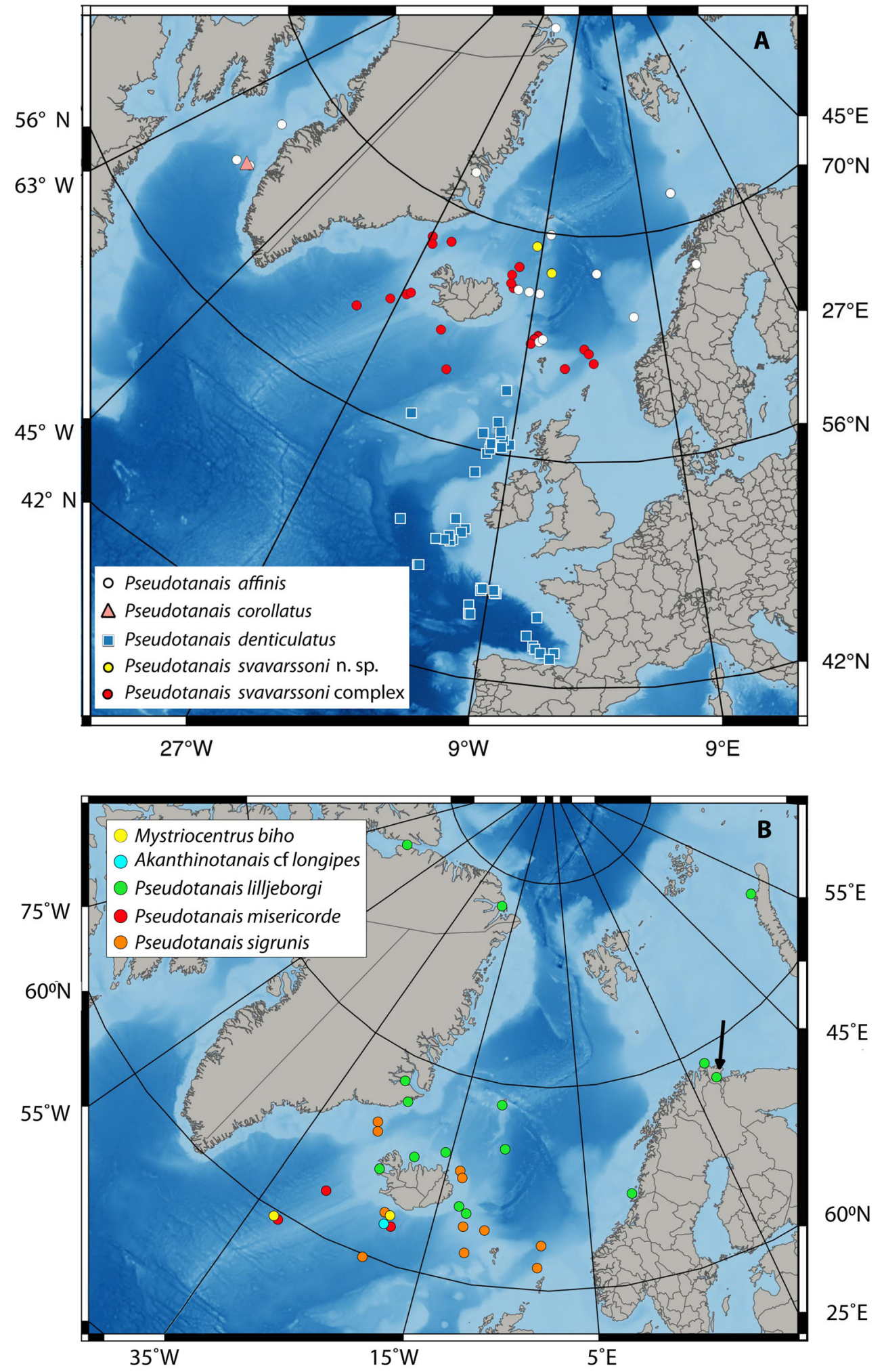

Diagnosis: Pereonite-2 similar in length to pereonite3; pereonite-3 clearly narrower, 0.8 times as wide as pereonite-4; maxilliped endites with small tubercles; pereopods 2-3 carpal blade-like spines long, 0.4 times as long as propodus.
Etymology: The name is composed of the first letters from the last names of Graham J. Bird and David M. Holdich, who erected the genus Mystriocentrus.

Description of ovigerous female: Body (Fig. 4) $1.9 \mathrm{~mm}$ length, 3.8 times as long as wide. Carapace $18 \%$ of total 




Fig. 8 Akanthinotanais cf. longipes, preparatory female. a Dorsal view. b Antennule. c Cheliped. Scale: $0.1 \mathrm{~mm}$

body length, subtriangular, 0.8 times as long as wide, with simple setae on each anterio-lateral margin. Pereon $55 \%$ of total body length, pereonite-1, half times as long as pereonite-2; pereonite-2 0.9 times as long as pereonite-3; pereonite-3, 0.8 times as wide as pereonite-4; pereonite- 4 1.2 times as long as pereonte-3; pereonite- 5 similar in length and width to pereonite-4; pereonite- 6 half times as long as pereonite-5; pereonites $0.1,0.2,0.3,1.2,1.2$, and 0.3 times as long as broad, respectively. Pleon $17 \%$ of total body length, with five similar in length pleonites, each 0.1 times as long as wide. Pleotelson $10 \%$ of body length; pleonites together with pleotelson as long as pereonites $4-6$ combined length.

Antennule (Fig. 5a) article-1 3.7 times as long as wide, with penicillate middle seta, one penicillate and one simple distal setae on outer margin; article-2 2.1 times as long as wide, half times as long as article-1, with simple and penicillate distal setae on inner margin; article-3 3.5 times as long as wide, as long as article-2, with one subdistal seta, tipped with one aesthetasc, one simple, one distally rounded, three distally furcate setae.
Antenna (Fig. 5b) article-1 fused, broken during dissection; article-2 1.5 times as long as wide, with seta on middle outer margin; article-3 1.3 times as long as wide, 0.8 times as long as article-2, with seta on proximal outer margin; article-4 four times as long as article-3, 6.3 times as long as wide, with two simple and one penicillate distal setae; article-5 3.4 times as long as wide, half times as long as article-4, with distal simple seta; article-6 vestigial, with one thickened, sensory seta and three simple setae distally.

Mouthparts. Labrum (Fig. 5c) rounded, hood-shape, naked. Left mandible (Fig. 5d) incisor distal margin blunt and serrated, lacinia mobilis large and distally serrated; molar acuminate and simple. Right mandible (Fig. 5e) with incisor distal margin serrated; lacinia mobilis fussed to a small process. Maxillule (Fig. 5f) distally bent, with eight slender distal spines. Maxilliped (Fig. 5g, h) endites completely fused, distal edges with small tubercles and lateral margins finely setose. Palp article- 1 and article- 2 naked; article-3 with three and one short setae on inner margin; article-4 with one thickened seta (Fig. 5h) and four simple inner and distal setae and one outer seta.

Cheliped (Fig. 6a) basis 1.6 times as long as wide; merus subtriangular, with simple midventral seta; carpus three times as long as wide, with two midventral setae, and with simple distodorsal seta; propodus (palm) as long as wide, small folds in distodorsal corner and small ventral seta; fixed finger 5.1 times as long as wide, 1.2 times as long as propodus, with serrated inner margin and three small inner setae; dactylus simple with slightly serrated inner margin.

Pereopod-1 (Fig. 6) basis 5.7 times as long as wide, with simple dorsoproximal seta; ischium 0.4 times as long as wide, naked; merus 1.8 times as long as wide, 0.6 times as long as carpus, naked; carpus 2.7 times as long as wide, 0.6 times as long as propodus, naked; propodus 6.6 times as long as wide, with dorsoproximal and distodorsal seta; dactylus 0.1 times as long as propodus, unguis 1.5 times as long as dactylus, together 0.5 times as long as propodus.

Pereopod-2 (Fig. 6c) basis 5.5 times as long as wide, with two simple ventral setae and with two penicillate dorsoproximal setae; ischium half times as long as wide, with simple seta; merus 1.5 times as long as wide, 0.9 times as long as carpus, with microtrichiae ventrally, spine and sensory seta distoventrally; carpus twice as long as wide, 0.6 times as long as propodus, with simple distodorsal seta and blade-like distoventral spine (0.4 times as long as propodus); propodus six times as long as wide, with distoventral spine; dactylus 0.2 times as long as propodus, unguis subequal propodus together almost as long as half of propodus.

Pereopod-3 (Fig. 6d) basis 3.5 times as long as wide, with one simple and one penicillate seta on ventral margin; ischium 0.3 times as long as wide, with simple ventral seta; merus 1.6 times as long as wide, and 1.1 times as long as carpus, with sensory seta and spine distoventrally; carpus half as long as 
wide, and 0.6 times as long as propodus, with microtrichiae ventrally, small distodorsal seta and blade-like spine distoventral spine ( 0.4 times as long as propodus); propodus six times as long as wide, with one distoventral spine; dactylus 0.3 times as long as propodus, unguis 0.6 times as long as dactylus, together 0.6 as long as propodus.

Pereopod-4 (Fig. 6e) basis six times as long as wide, with ventroproximal simple seta; ischium 0.6 times as long as wide, with simple seta; merus 1.8 times as long as wide, 0.6 times as long as carpus with simple distoventral seta; carpus five times as long as wide, subequal propodus, with blade-like spine (broken) and spine distoventrally, and with sensory seta distodorsally; propodus six times as long as wide, with two distoventral setae and long distodorsal seta; dactylus with unguis half as long as propodus; unguis 0.2 as long as dactylus.

Pereopod-5 (Fig. 6f) as pereopods-4, but carpus with one sensory seta and one simple seta, on dorsal margin distally, with one spine and with one blade-like spine ventral margin.

Pereopod-6 (Fig. 6g) similar to pereopod-4 but basis 3.7 times as long as wide, carpus with one sensory seta, one simple seta, one spine and one blade-like spine; propodus with four setae terminally.

Pleopoda (Fig. 6i) basal article 3.6 as long as wide, endopod 5.3 as long as wide, with four distal setae; exopod 3.3 as long as wide, with eight distal setae.

Uropod (Fig. 6h) basal article as long as wide, naked; exopod 1.7 times as long as basis, and as long as endopod article-1, with two articles, article-1 1.3 times as long as article-2, with distal seta, article-2 with one small subdistal and one strong distal setae; endopod 1.8 times as long as exopod, with two articles; article-1 1.2 times as long as article-2, with long simple seta distally on outer margin; article- 2 with three long simple and two short penicillate setae distally.

Distribution: M. biho sp. n. was recorded in Irminger and Iceland Basins at the depth range 913-2540 m (Fig. 7b). The new species is the second member of the genus Mystriocentrus, that is so far known only from the North Atlantic (Fig. 2b).

Remarks: The Mystricentrus biho sp. n. can be recognized from the congener M. serratus Bird and Holdich, 1989a, b by the proportion of pereonites $2-3$. In the new species, the pereonite- 2 is similar in length to pereonite-3, but twice as long as pereonite3 in M. serratus. Beside that, pereonite-3 is visibly narrower than rest of the pereonites ( 0.8 times as wide as pereonite- 4 ) in the new species, but similar size in $M$. serratus. Additionally, $M$. biho. sp. n. has one sensory (spatulate) setae on merus and carpus of the pereopods $2-6$, while in $M$. serratus one to three such setae present; blade-like spine on pereopods $2-3$ carpus are clearly longer ( 0.4 times as long as propodus) in $M$. biho than in $M$. serratus (0.1-0.2 times as long as propodus). Finally, the new species can be distinguished by appearance of maxilliped endite that has small tubercles on the distal margin; the distal margin of maxilliped endites in M. serratus is smooth.

Genus Akanthinotanais Sieg, 1977
Diagnosis (after Sieg 1977): Pereopods without blade-like spines.

Remarks: The Pseudotanaidae is a morphologically consistent family with few autapomorphic characters (Bird and Holdich, 1989a). Distinguished by Sieg (1977), two subgenera-Akanthinotanis (Sieg, 1977) and Pseudotanais (Sieg, 1977)—were seen by McLelland (2008) distinct enough to erect them as genera or even subfamily. Although the research by McLelland unfortunately were never published, Bird and Larsen (2009) treated the two taxa as valid genera in their phylogenetic analyses adding in its result two other genera Mystriocentrus Bird and Holdich, 1989b and Parapseudotanais Bird and Holdich, 1989a.

The phylogenetic analysis is beyond the purpose of this paper, but it is essential to mention that molecular markers approach ascertain Pseudotanais itself as not monophyletic and highly diverse taxon (Jakiel and Błażewicz, in preparation), that can be straightforwardly split into at least few new genera. Furthermore, the same approach apparently demonstrated that Akanthinotanais is not monophyletic with Pseudotanais supporting McLelland proposition to treat them both as valid genera.


Fig. 9 Pseudotanais misericorde sp. n., preparatory female. a Dorsal view. b Lateral view. Scale: $0.1 \mathrm{~mm}$ 
Fig. 10 Pseudotanais misericorde sp. n., preparatory female. A antennule, B antenna, C left mandible, D right mandible, $\mathrm{E}$ maxillule endite, E' maxillule palp, F maxilla, and $\mathrm{G}$ maxilliped. Scale: $0.1 \mathrm{~mm}$ for A-B and $0.01 \mathrm{~mm}$ for $\mathrm{C}-\mathrm{G}$

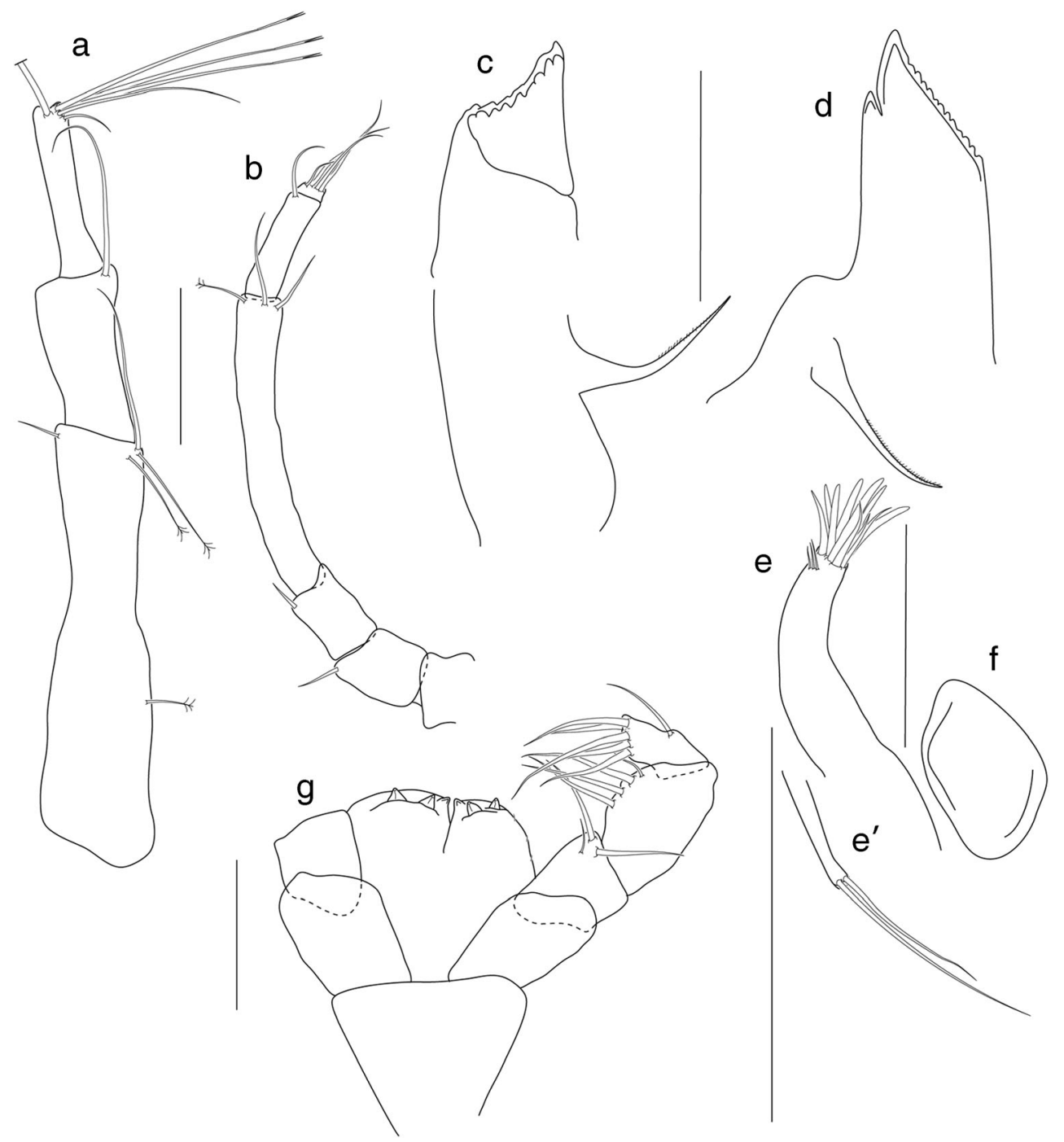

\section{Akanthinotanais cf. longipes}

Fig. 8

Material examined: one neutrum, ZMH K-54853, St. 1010$1,62^{\circ} 33.17^{\prime} \mathrm{N} 20^{\circ} 23.18^{\prime} \mathrm{W}-62^{\circ} 33.22^{\prime} \mathrm{N} 20^{\circ} 22.88^{\prime} \mathrm{W}$, depth 1383.3-1387.8 m, EBS, 02 Sep 2011.

Distribution: Akanthinotanais longipes was described by Hansen (1913) from Ingolf Expedition (st. 78; 60 $37^{\prime} \mathrm{N} 27^{\circ} 52^{\prime} \mathrm{W}$, depth $364 \mathrm{~m}$, temp. $4.5^{\circ} \mathrm{C}$ ) in the Iceland Basin and so far it is the only known location of the species (Fig. 2c).

In the IceAGE collection, the only specimen presumably conspecific with A. longipes was found in Iceland Basin at the depth 1387 m (Fig. 7b).

Remarks: As the only individual collected during the IceAGE cruises was preserved in poor condition, its full identification and comparison of details with those of Akanthinotanais longipes (Hansen, 1913) was not possible. However, the absence of eyes, the presence of slender antennule and cheliped, and the absence of a bladelik seta on pereopod-1 allowed us to regard it as conspecific with $A$. longipes. Only three akanthinotanaids known at present are blind, but only $A$. longipes is elongated (3.0 times as long as it is wide) and has a not-forcipate cheliped. Two other blind akanthinotanaids Akanthinotanais gaussi (Vanhöffen, 1914) and Akanthinotanais similis (Sieg, 1977) have rather robust chela which is 2.0 and 2.5 times, respectively, as long as it is wide.

Genus Pseudotanais G.O. Sars, 1882

Pseudotanais misericorde sp. $\mathrm{n}$.

Figs. 9, 10, and 11

Material examined: Holotype: neutrum, ZMH K-54854, St. $1054-1,61^{\circ} 36.82^{\prime} \mathrm{N} 31^{\circ} 22.26^{\prime} \mathrm{W}-61^{\circ} 36.98^{\prime} \mathrm{N} 31^{\circ}$ 22.18' W, depth 2545.7-2536.8 m, EBS, 07 Sep 2011.

Paratypes: neutrum (dissected), ZMH K-54855, St. 1010$1,62^{\circ} 33.17^{\prime} \mathrm{N} 20^{\circ} 23.18^{\prime} \mathrm{W}-62^{\circ} 33.22^{\prime} \mathrm{N} 20^{\circ} 22.88^{\prime} \mathrm{W}$, depth 1383.3-1387.8 m, EBS, 02 Sep 2011; three neutri (two dissected), ZMH K-54856, St. 1054-1, 61 ${ }^{\circ} 36.82^{\prime} \mathrm{N} 31^{\circ}$ $22.26^{\prime} \mathrm{W}-61^{\circ} 36.98^{\prime} \mathrm{N} 31^{\circ} 22.18^{\prime} \mathrm{W}$, depth 2545.7 -2536.8 m, EBS, 07 Sep 2011; neutrum ZMH K-54857, St. 
Fig. 11 Pseudotanais misericorde sp. n., preparatory female. a Cheliped. b Pereopod1. c Pereopod-2. d Pereopod-3. e Pereopod-4. f Pereopod-5. g Pereopod-6. h Uropod. i Pleopod. Scale: $0.1 \mathrm{~mm}$

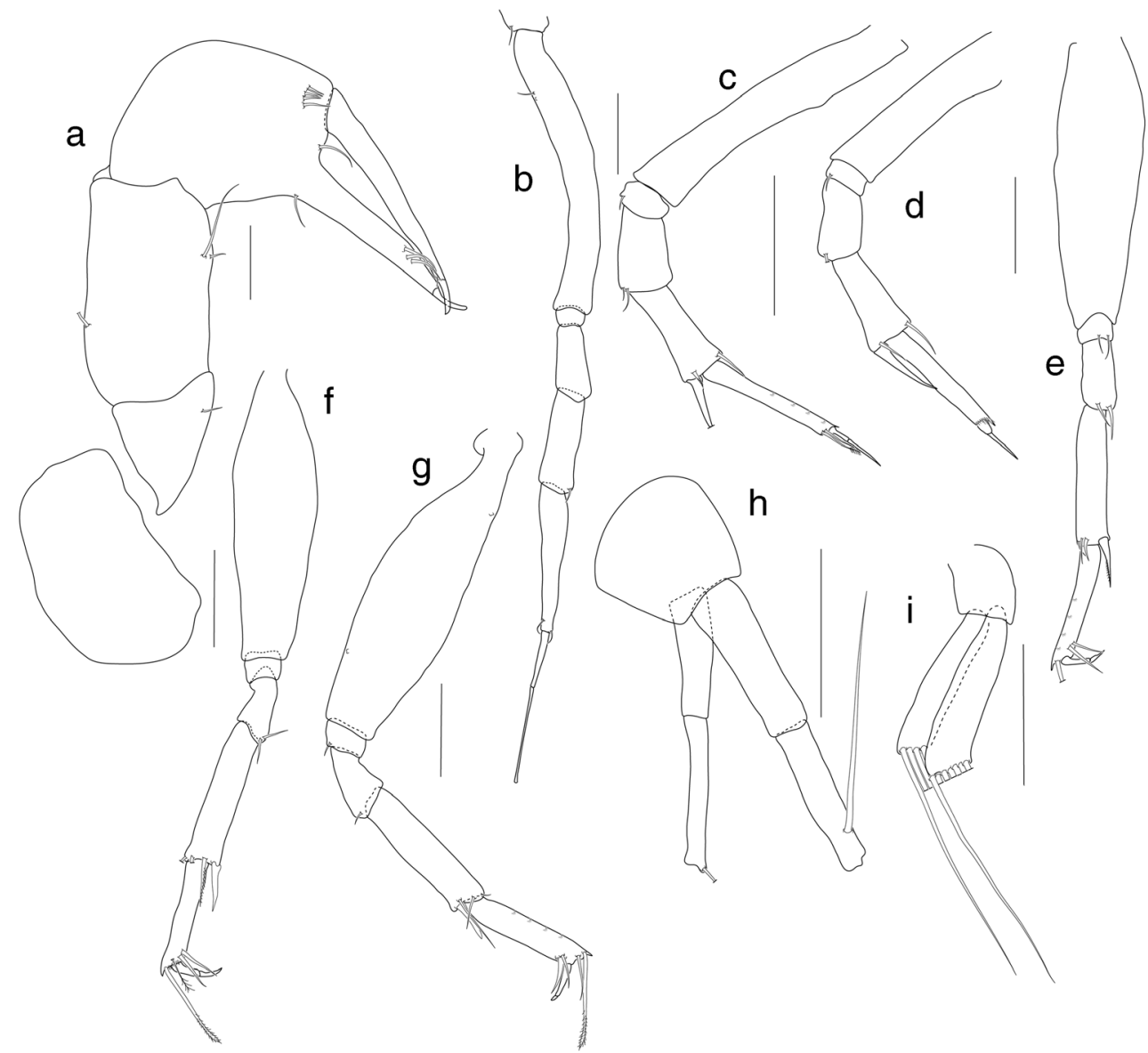

$1066,62^{\circ} 59.97^{\prime} \mathrm{N} 028^{\circ} 04.78^{\prime} \mathrm{W}$, depth $1621.8 \mathrm{~m}, \mathrm{GKG}, 08$ Sep 2011.

Diagnosis: Eyes absent. Pereonites 2-3 the same length. Antennule article-1 six times as long as wide. Antenna articles 2-3 with simple setae. Maxilliped molar pointed with upper margin serrated. Maxilliped endites with conical tubercles. Cheliped carpus 1.6 times as long as wide. Chela forcipate, unguis, and dactylus distal spines inside bent. Pereopods 2-6 blade-like spine slender and pointed. Uropod exopod two articulated, 0.8 times as long as endopod.

Etymology: From Latin misericorde was called the long and narrow knife used in medieval for delivering a mercy stroke. The name refers to the unusual shape of the bladelike spine on pereopods $2-6$, that is long and pointed.

Description of neutrum: Body (Fig. 9a, b) $1.8 \mathrm{~mm} ; 5.0$ times as long as broad. Carapace almost as long as pereonites 1-3 and half of pereonite-4 combined, naked, lateral margin gently rounded. Pereon $39 \%$ of total body length, pereonite- 1 half as long as pereonite-2; pereonites 2 the same length and pereonites 3, wilt lateral setae; pereonite-3 half as long as pereonite-4; pereonite-4 as long as pereonites-5; pereonite-5 1.2 times as long as pereonites- 6 , pereonites $0.1,0.2,0.2,0.5$, 0.5 , and 0.4 times as long as broad, respectively (data for the holotype). Pleon $22.7 \%$ of total body length, pleonite-1 slightly wider than all other pleonites. Pleotelson $13 \%$ of total body length pleonites together with pleotelson almost as long as pereonites $2-6$ combined length.

Antennule (Fig. 10a) article-1 six times as long as wide, with middle penicillate seta, one simple and two penicillate distal setae on inner margin and simple distal seta on outer margin; article-2 2.1 times as long as wide, with distal seta longer that article-3 on inner margin; article-3 just longer than article-2, with six distal setae: two simple and three distally trifurcate seta, one seta broken.

Antenna (Fig. 10b) shorter than antennule; article-1 fussed with body; article-2 1.1 times as long as wide, with one seta on outer margin; article-3 1.5 times as long as wide, subequal to article-2 with one seta on outer margin; article- 43.5 times as long as article 3, 7.4 times longer than broad, with two simple and one penicillate setae distally; article- 50.3 times as long as article- 4 , with one simple seta distally; article 6 vestigial, with four simple setae distally.

Mouthparts. Labium not observed. Left mandible (Fig. 10c) incisor distal margin blunt and serrated, lacinia mobilis large, and distally serrated; molar acuminate; right mandible (Fig. 10d) with incisor distal margin serrated; lacinia mobilis fussed to a small process. Maxillule (Fig. 10e) distally bent, with eight spines and two setae 
distally, three fine setae subdistally on outer margin; endite (Fig. 10e') with two distal setae. Maxilla (Fig. 10f) ovoid, naked. Maxilliped (Fig. 10g) endites completely fused except the most distal fragment, where they stay well separated; distal margin with two conical tubercles, each with visible distal hole, and finely setose lateral margins. Palp article-1 naked, article-2 with three inner setae (two long one short), article-3 with four inner setae (three long and one short), article-4 with and five simple inner and distal setae and one middle outer seta.

Cheliped (Fig. 11a) basis 1.6 times as long as wide; merus subtriangular with single midventral seta; carpus 1.7 times as long as broad, with two midventral (long and short) setae; dorsal margin with simple submiddle distal seta not seen; chela forcipate, propodus (palm) 1.3 times as long as wide and 0.9 times as long as fixed finger, with ventral seta and one seta near dactylus insertion; row of five small setae on inner surface; fixed finger with three seta, distal spine bent upward; dactylus simple as long as fixed finger, distal spine bent downward.

Pereopod-1 (Fig. 11b) slender, basis 7.9 times as long as wide with two dorsoproximal setae (one broken); ischium naked; merus 2.3 times as long as wide, 0.2 times as long as basis, naked; carpus 3 times as long as wide 0.6 times as long as propodus, with fine distodorsal seta; propodus 7 times as long as wide, with two fine distal seta; dactylus 0.3 as long as propodus, dactylus 0.6 times as long as unguis; dactylus and unguis combined as long as propodus.

Pereopod-2 (Fig. 11c) basis 6.5 times as long as wide; ischium with simple seta; merus 1.5 times as long as wide, 0.7 times as long as carpus, with two setae distally; carpus 2.7 times as long as wide, 0.7 times as long as propodus with two setae and one blade-like spine, very slender spine (distally broken) distally; propodus 8.3 times as long as wide with plumose seta distally, ventral margin with microtrichiae; unguis twice as long as dactylus, combined half as long as propodus.

Pereopod-3 (Fig. 11d) similar to pereopod-2, but carpus 2.6 times as long as propodus and propodus 5 times as long as wide, without microtrichiae; blade-like spine on carpus 0.6 times as long as propodus.

Pereopod-4 (Fig. 11e) basis 3.3 times as long as wide, naked; ischium with two setae; merus 0.2 times as long as wide; 0.4 times as long as carpus, with two distal setae; carpus 4.5 times as long as wide, 1.2 times as long as propodus, with blade-like spine ( 0.4 times as long as propodus) and with three setae distally; propodus 6.2 times as long as wide, with two ventrodistal simple setae and dorsodistal seta broken; dactylus twice as long as unguis.

Pereopod-5 (Fig. 11f) basis 3.4 times as long as wide; ischium naked (setae probably broken off); merus 2.6 times as long as wide, 0.5 times as long as carpus, with two distal setae; carpus 4.3 times as long as wide, 1.2 times as long as

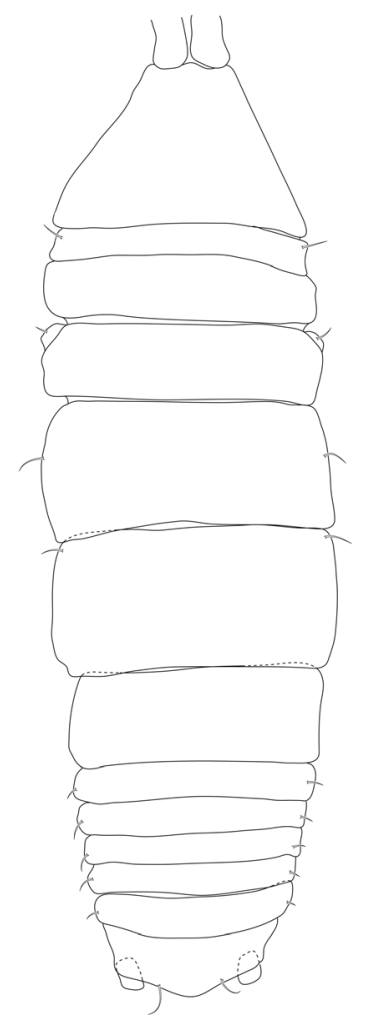

Fig. 12 Pseudotanais svavarssoni sp. n., neutrum, holotype (cat no...), dorsal view. Scale: $0.1 \mathrm{~mm}$

propodus, with blade-like spine (0.4 times as long as propodus) and three setae distally (one serrate, two broken); propodus 5.2 times as long as wide, with two distoventral simple setae, one subdistal penicillate seta and one dorsodistal serrated, distally flatten seta; dactylus 1.4 times as long as unguis.

Pereopod-6 (Fig. 11g) basis 3.8 times as long as wide with dorsoproximal seta (broken off); ischium with one seta (second seta probably broken off); merus 2.1 times as long as carpus with one distal seta (second seta probably broken off); carpus 3.8 times as long as wide and 1.1 times as long as propodus, with three simple setae and one blade-like spine ( 0.3 times as long as propodus), distally; propodus 4.8 times as long as wide with two simple distoventral setae, one simple and one distally serrated, dorsodistal flatten setae; dactylus 5 times as long as unguis.

Pleopod (Fig. 11i) endopod 4.5 times as long as wide, with four distal setae; exopod four times as long as wide with seven distal setae.

Uropod (Fig. 11h) basis naked; exopod 0.8 times as long as endopod, with two articles, article-1 0.8 times as long as article-2, article-2 with at least one distal seta (broken); endopod with two, subequal articles, article- 2 with at least one subdistal seta.

Distribution: P. misericorde was recorded in the Iceland and Irminger Basins (Fig. 7) at the depth range: from 1383 to $2545 \mathrm{~m}$. 
Fig. 13 Pseudotanais svavarssoni sp. n., preparatory female. A antennule, B antenna, C labrum, D left mandible, E right mandible, F maxillule endite, F' maxillule palp, $\mathrm{G}$ maxilla, $\mathrm{H}$ labium, I maxilliped, J epignath. Scale: $0.1 \mathrm{~mm}$ for A-B and 0.01 for $\mathrm{C}-\mathrm{J}$

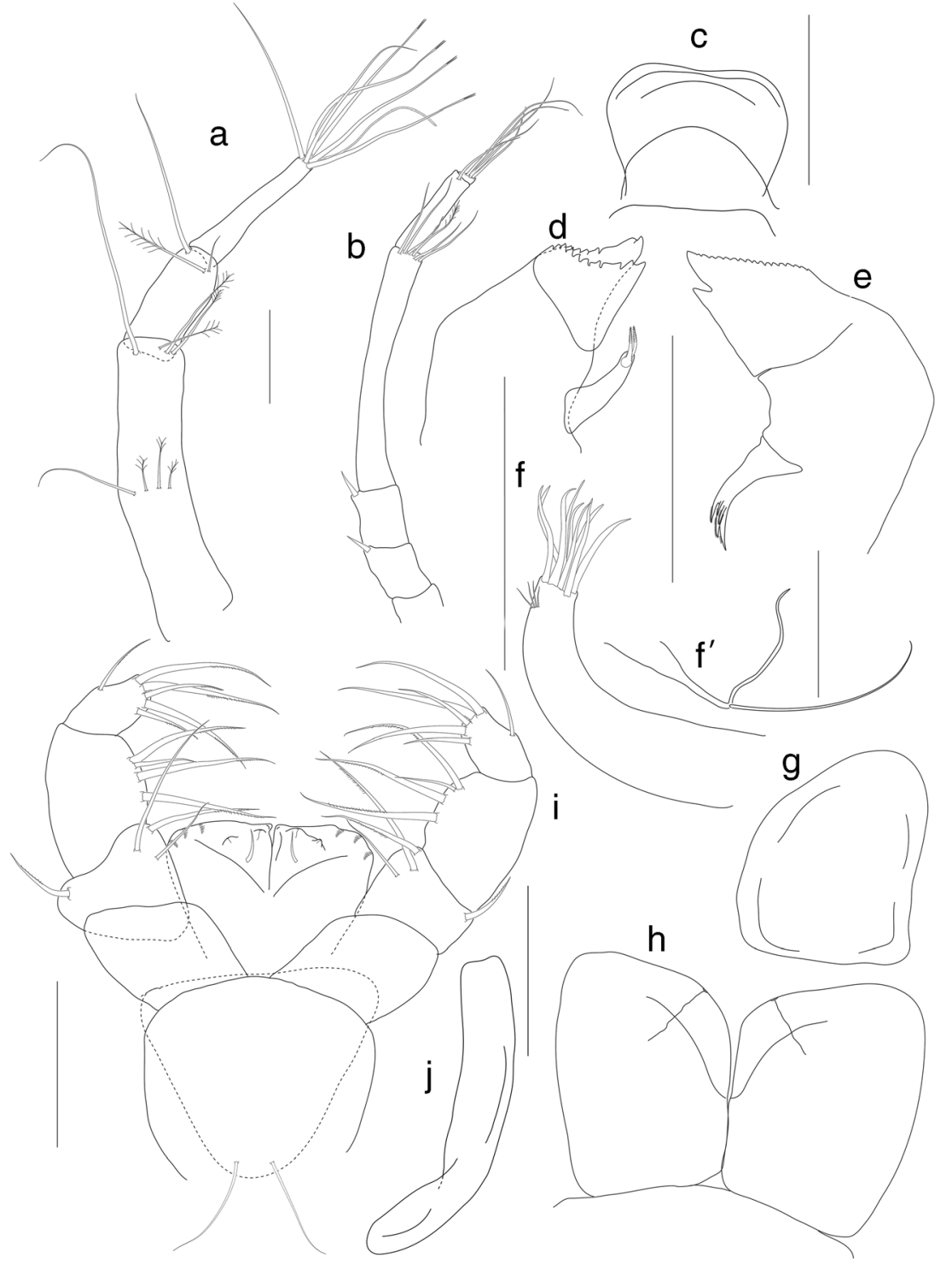

Remarks: Pseudotanais misericorde sp. n. represents the group of blind pseudotanaids with a forcipate chela and exopod of the uropod almost as long as the endopod. These two characters delineate also Pseudotanais vulsella Bird and Holdich, 1989b and P. falcicula Bird and Holdich, 1989a, both recorded in Porcupine Bank and Rockall Trough.

$P$. misericorde, as $P$. vulsella, has the same conical tubercles on distal margin of maxilliped endites but the new species can be distinguished from $P$. vulsella by slender blade-like carpal spines ("blade" part is much narrower than in all other species). In P. falcicula tubercles in edge of the maxilliped endites are very small (Bird and Holdich, 1989b, Fig. 19g) besides straight distal spines in chela dactylus and fixed finger, what allow to comfortably distinguish it $P$. falcicula from the new species.

Pseudotanais svavarssoni sp. $\mathrm{n}$.

Figs. 12, 13, and 14
Material examined: Holotype: neutrum ZMH K-54858, $1168-1,67^{\circ} 36.38^{\prime} \mathrm{N} 007^{\circ} 00.08^{\prime} \mathrm{W}$, depth $2372.6 \mathrm{~m}$, EBS, 19 Sep 2011.

Paratypes: five neutri, one manca, ZMH K-54859, St. $1152-1,69^{\circ} 5.60^{\prime} \mathrm{N} 9^{\circ} 56.01^{\prime} \mathrm{W}$, depth $2172.6 \mathrm{~m}$, GKG, 17 Sep 2011; neutrum, ZMH K-54860, St. 1155-1, 6906.89' N $009^{\circ} 54.72^{\prime} \mathrm{W}$, depth $2203.8 \mathrm{~m}$, EBS, 17 Sep 2011; 92 neutri, 35 juvenile males, ZMH K-54861, St. 1159-1, 6906.66 ${ }^{\prime} \mathrm{N}$ $009^{\circ} 55.02^{\prime} \mathrm{W}$, depth $2202.8 \mathrm{~m}$, EBS, 17 Sep 2011; one neutrum, one juvenile male, ZMH K-54862, St.1166-1, $67^{\circ}$ $35.28^{\prime} \mathrm{N} 6^{\circ} 57.47^{\prime} \mathrm{W}$, depth $2401.8 \mathrm{~m}$, GKG, 19 Sep 2011; 43 neutri, (one dissected), five juvenile males ZMH K-54863,

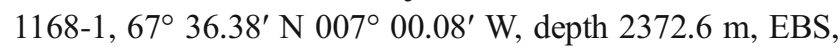
19 Sep 2011.

Diagnosis: Eyes absent. Carapace, pereonites, and pleonites combined length range between 1.2 and $1.7 \mathrm{~mm}$. Pereonite-1 the shortest. Antennule article-1 four times as long 
Fig. 14 Pseudotanais svavarssoni $\mathrm{sp} . \mathrm{n}$., preparatory female. A cheliped, B pereopod1, C pereopod-2, D pereopod-3, E pereopod-4, F pereopod-5, G pereopod-6, $\mathrm{H}$ uropod, and I pleopod. Scale: $0.1 \mathrm{~mm}$

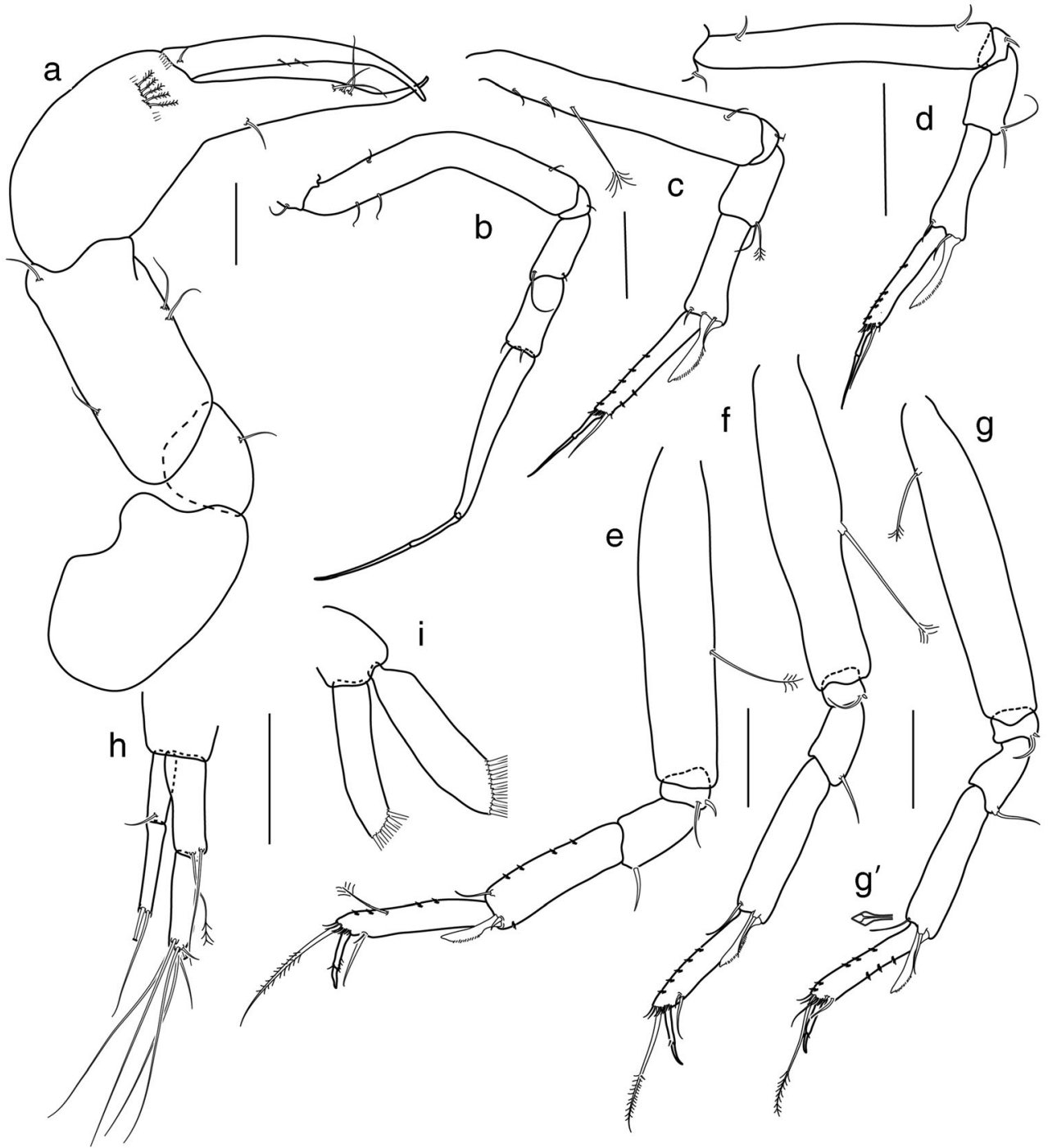

as wide. Antenna articles 2-3 with distal simple setae. Left mandible with two teeth. Maxilliped endites with small tubercles. Cheliped elongated, carpus 1.7-2.1 times as long as wide, propodus 1.4-1.6 times as long as wide. Pereopod-1 propodus $2.2-2.5$ times as long as carpus, propodus $1.1-1.3$ times as long as combined length of dactylus and unguis. Pereopods 2-6 carpal blade-like spine well developed. Pereopod-3 propodus $1.4-1.7$ times as long as blade-like spine. Pereopod-6 propodus 2.6-6.4 times as long as distal carpal seta ratio. Females with pleopods. Uropod exopod two articulated, 0.8 times as long as endopod.

Etymology: The species named after Jörundur Svavarsson, a professor in marine biology at the University of Iceland, the great enthusiast of Icelandic nature and wonderful fellow on the land as well as on the sea.

Description of neutrum: Body (Fig. 12) $1.7 \mathrm{~mm}$ long, over three times as long as wide. Carapace $18 \%$ of total body length, subtriangular, naked. Pereon $58 \%$ of total body length, pereonite-1, 0.4 times as long as pereonite-2; pereonite20.9 times as long as pereonite-3; pereonite- 30.6 times as wide as pereonite-4; pereonite-4 0.8 times as long as pereonte-5; pereonite-5 1.5 times as long as pereonite-6; pereonites $1-6: 0.1,0.3,0.3,0.4,0.5$, and 0.4 times as long as wide, respectively; pereonites 1,4 , and 5 with one lateral seta on each margin. Pleon $18.8 \%$ of total body length, with five similar in length pleonites, each 6.4 times as long as wide, with one seta on lateral margin. Pleotelson $6 \%$ of total body length; pleonites together with pleotelson almost as long as pereonite-2, two setae on pleotelson distal margin.

Antennule (Fig. 13a) article-1 4.0 times as long as wide, with long simple, and three midlength penicillate setae, and three penicillate and long simple seta distally; article- 2.2 times as long as wide, and 0.4 times as long as article-1, with one outer distal seta longer that article-3, one penicillate and one simple seta distally; article-3 1.2 times as long as article-2, with two simple and four distally trifurcate and one aesthetasc, distally. 


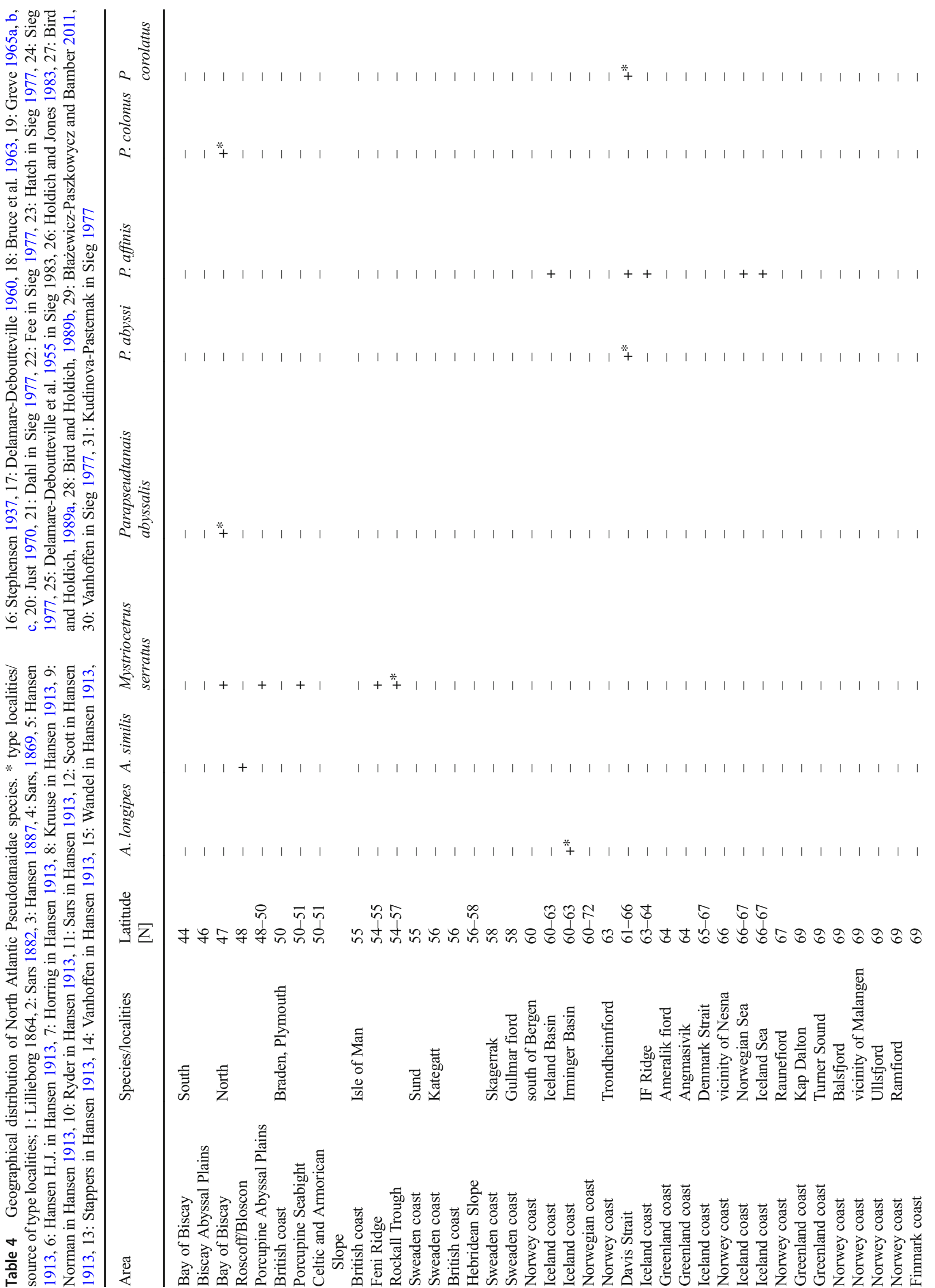









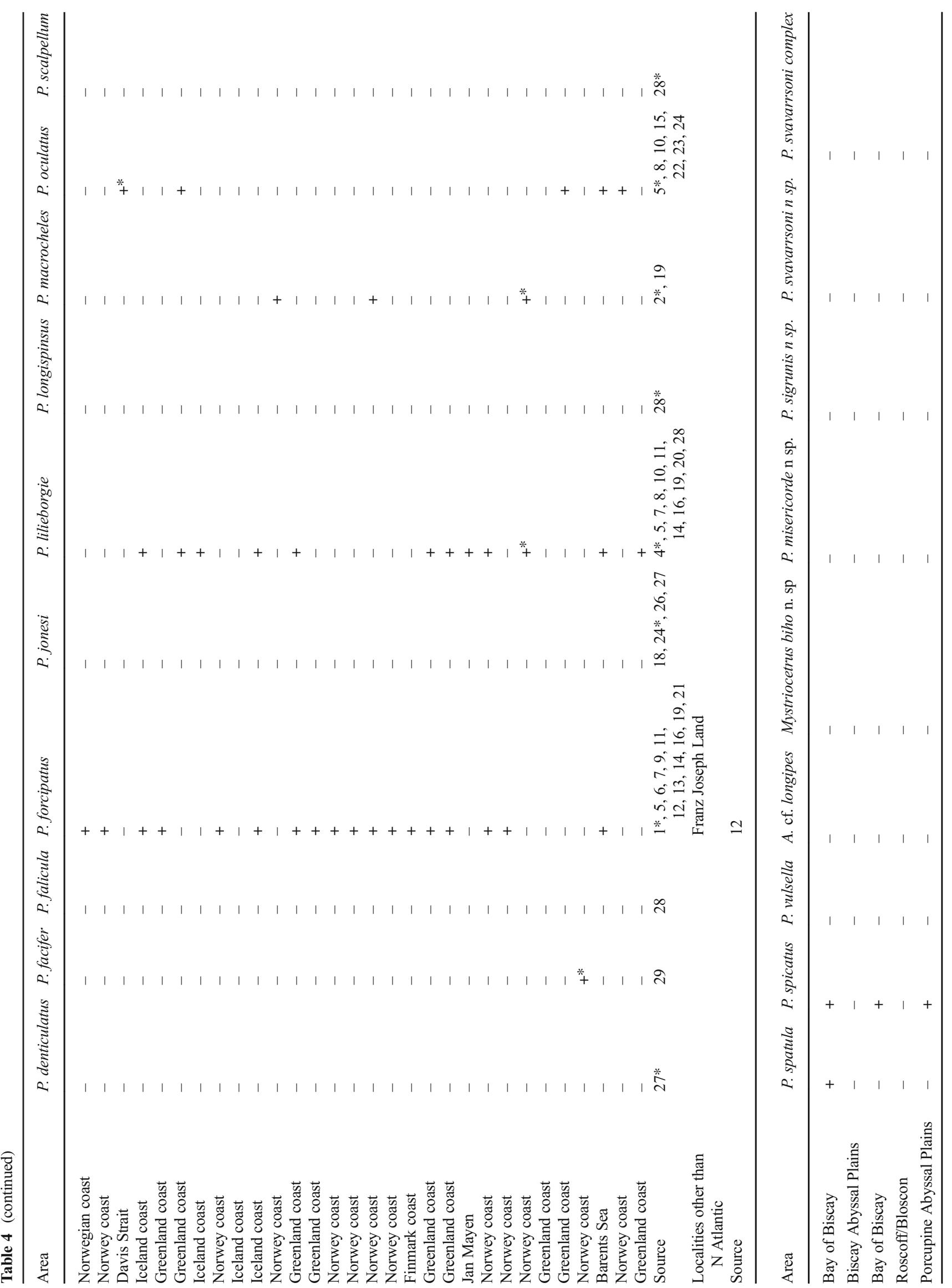




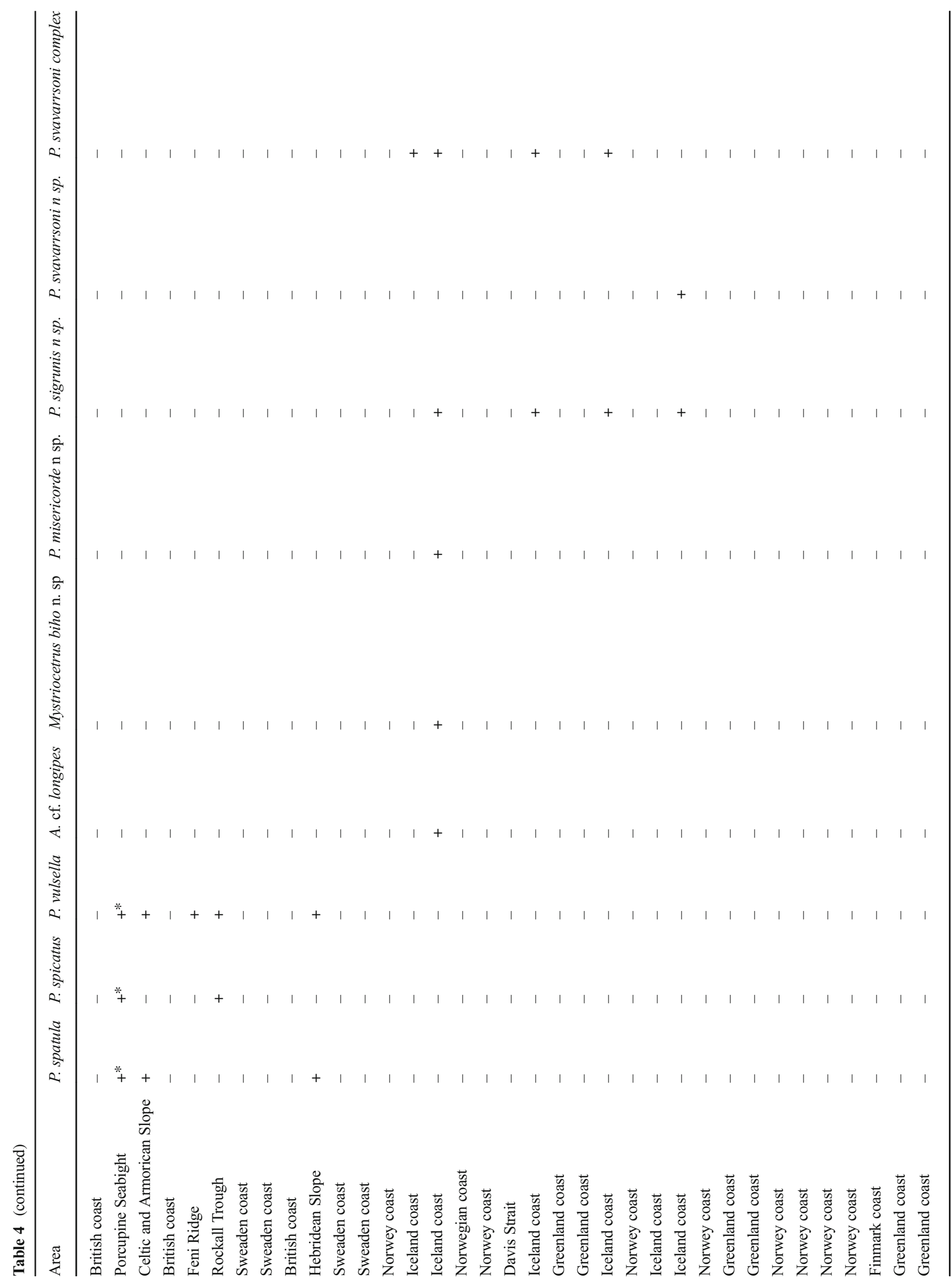




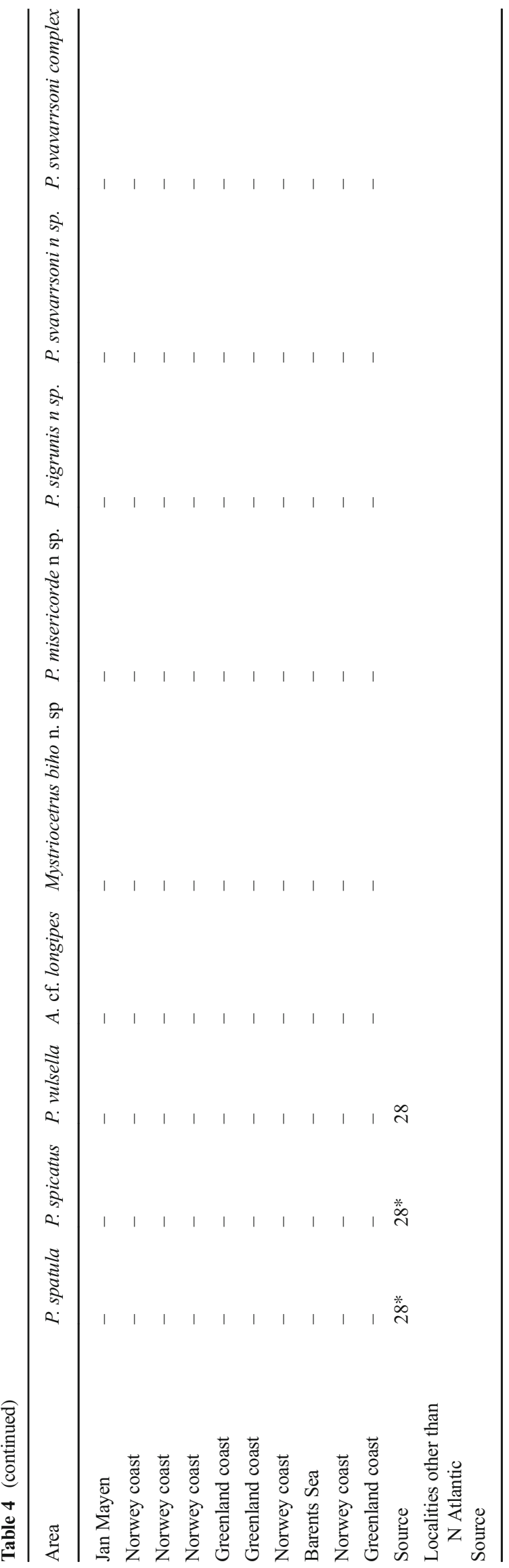

Antenna (Fig. 13b) shorter than antennule; article-1 fussed with body, broken during dissection; article-2 1.1 times as long as wide, with spine on outer margin; article- 3 as article2; article-4 8.0 times as long as wide, with five simple and one penicillate setae, distally; article-5 2 times as long as wide, 0.3 times as long as article-4, with simple distal seta; article-6 short, with five simple distal setae.

Mouthparts. Labrum (Fig. 13c) rounded, hood-shape, naked. Left mandible (Fig. 13d) incisor margin irregularly serrated, lacinia mobilis large and irregularly serrated; molar acuminate with two serrated distal spines. Right mandible (Fig. 13e) with regularly serrated incisor, lacinia mobilis fussed to a small process; molar acuminate, with five serrated distal spines. Maxillule (Fig. 13f) distally bent, with nine distal setae and four subdistal fine setae on outer margin endite (Fig. 13f') with two distal setae. Maxilla (Fig. 13g) suboval distally, proximal margin flattened, naked. Labium (Fig. 13h) simple (accessory lobe not seen), naked. Maxilliped (Fig. 13i) basis short, almost as long as wide with two simple proximal setae directed posteriorly to main axis of the body; endites partly fussed, distally separated, distal edge with one seta and a pair of small tubercles on each side, lateral margins finely setose. Palp article-1 naked; article-2 with three setae on inner margin and one seta on outer margin.; article-3 with three long and one short seta on inner margin; article-4 with five simple setae on inner distal margin and one seta on outer margin. Epignath (Fig. 13j) naked, linguiform.

Cheliped (Fig. 14a) basis 1.5 times as long as broad; merus subtriangular, with midventral seta; carpus 2.0 times as long as broad, with two midventral setae, and with one subproximal and one distal setae on dorsal margin; chela not-forcipate, slender; propodus (palm) 1.9 times as long as wide, little shorter than fixed finger, and row of five serrated setae on inner side; fixed finger with three setae on cutting edge and one ventral seta, distal spine bent upward; dactylus as long as fixed finger with two seta on inner margin, with distal spine bent downward.

Pereopod-1 (Fig. 14b) slender, coxa with simple seta; basis 6.7 times as long as wide, with two dorsoproximal and one distoventral setae; ischium with one seta, merus 2 times as long as wide, 0.8 times as long as carpus with short distoventral and long dorsoproximal setae; carpus 2.5 times as long as wide, 0.4 times as long as propodus, with two small distal setae; propodus 6.6 times as long as wide, naked; dactylus 0.3 times as long as propodus; unguis 1.8 times as long as dactylus, combined 0.9 times as long as propodus.

Pereopod-2 (Fig. 14c) basis seven times as long as wide, with two simple and one penicillate seta dorsoproximally, one distoventral seta; ischium with small simple seta; merus 1.8 times as long as wide, 0.7 times as long as carpus, with simple and penicillate setae distoventrally; carpus 3.3 times as long as wide, 0.6 times as long as propodus, with two simple setae and long blade-like spine propodus 7 times as long as wide, with simple distal seta; numerous microtrichiae in distal half; 


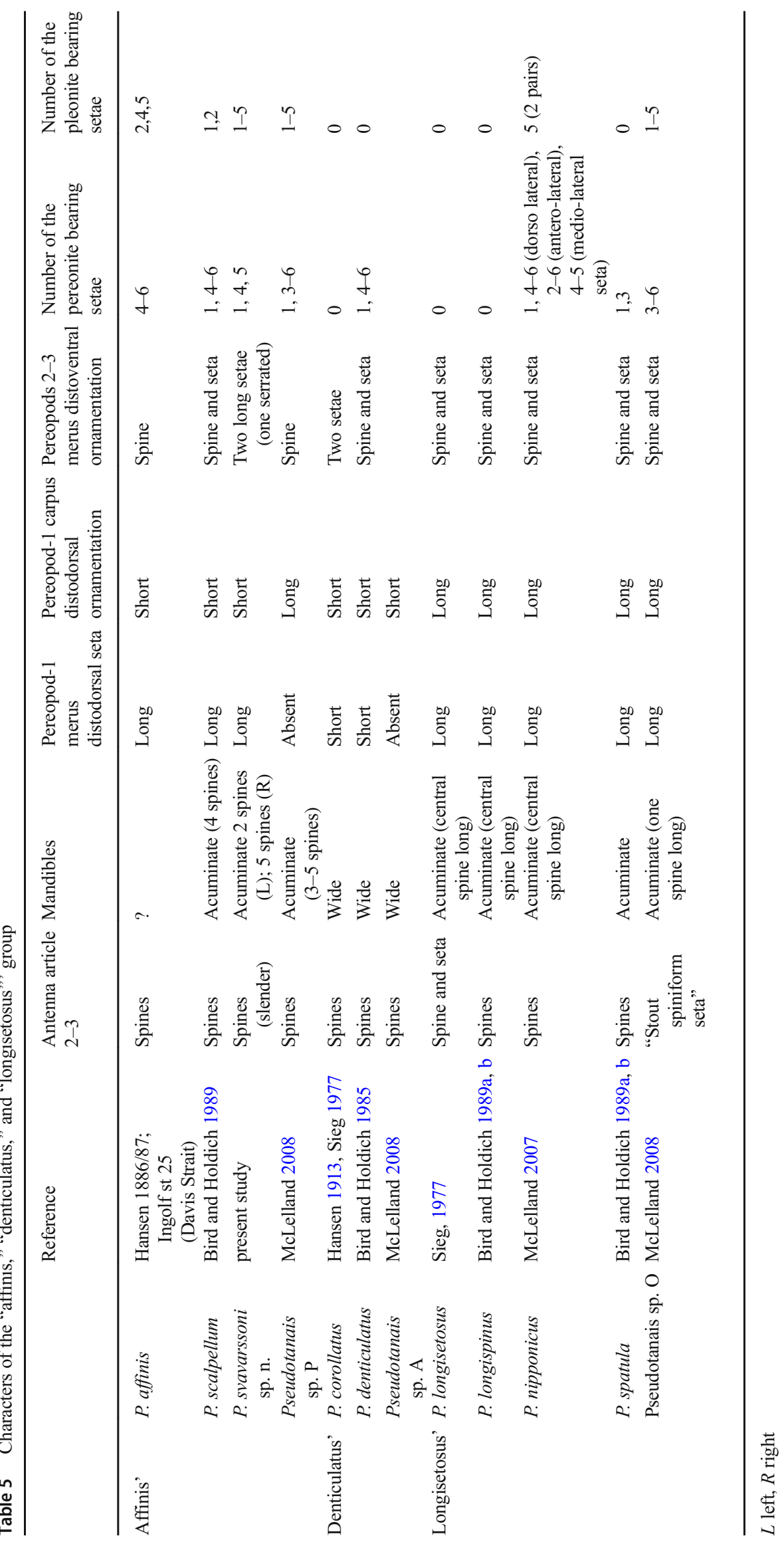


Fig. 15 Pseudotanais sigrunis sp.

n. preparatory female, holotype

(cat no...). a Dorsal view. b

Lateral view. Scale: $0.1 \mathrm{~mm}$
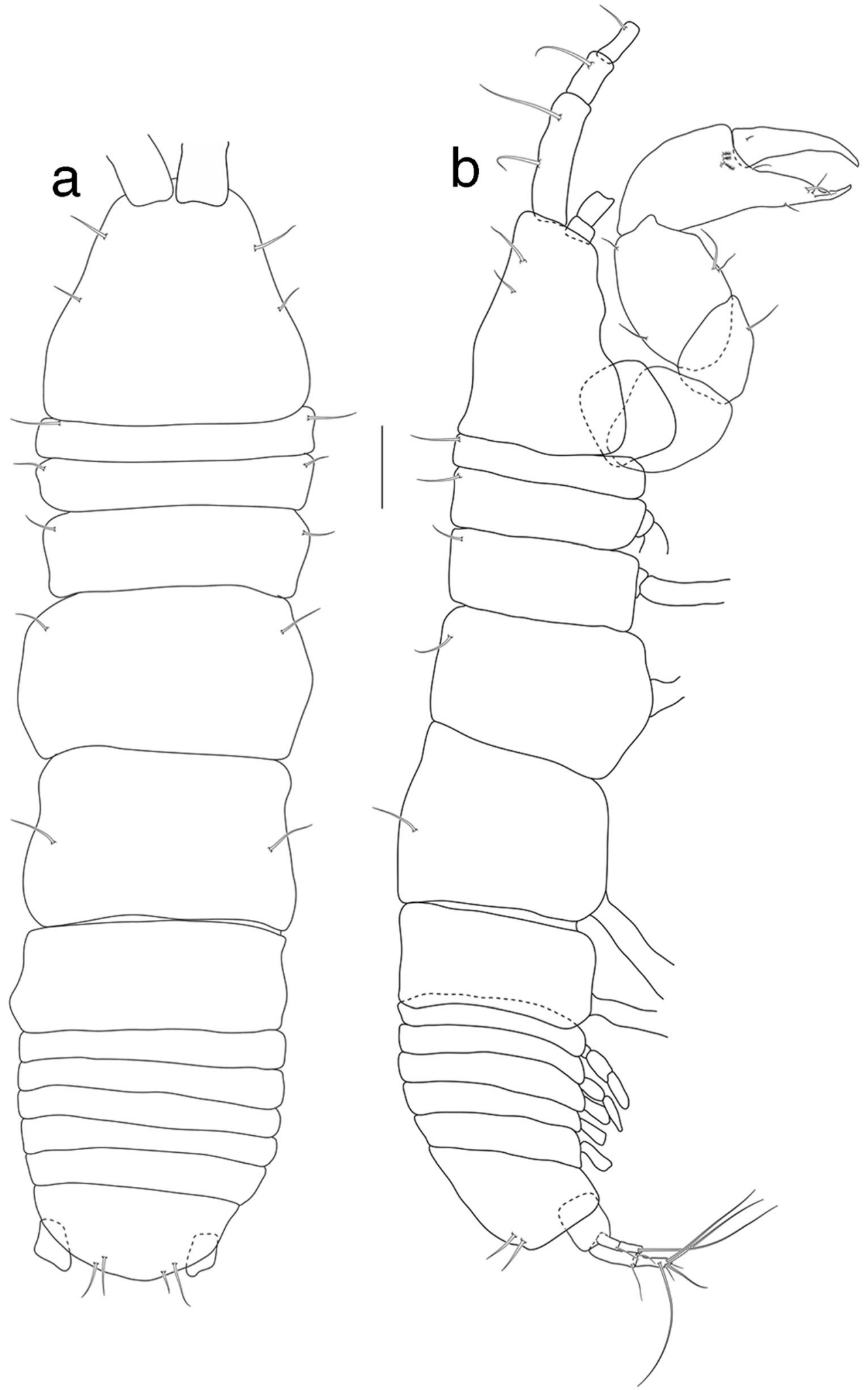

dactylus 0.6 times as long as propodus, unguis 1.7 times as long as dactylus, together 0.9 times as long as propodus.

Pereopod-3 (Fig. 14d) similar to pereopod-2, but basis with ventroproximal and ventrodistal simple setae; carpus 0.9 times as long as propodus, blade-like spine 0.7 times as long as propodus; propodus 7.3 times as long as wide.

Pereopod-4 (Fig. 14e) 4.1 times as long as wide, with penicillate midventral seta; ischium with one short and one long 


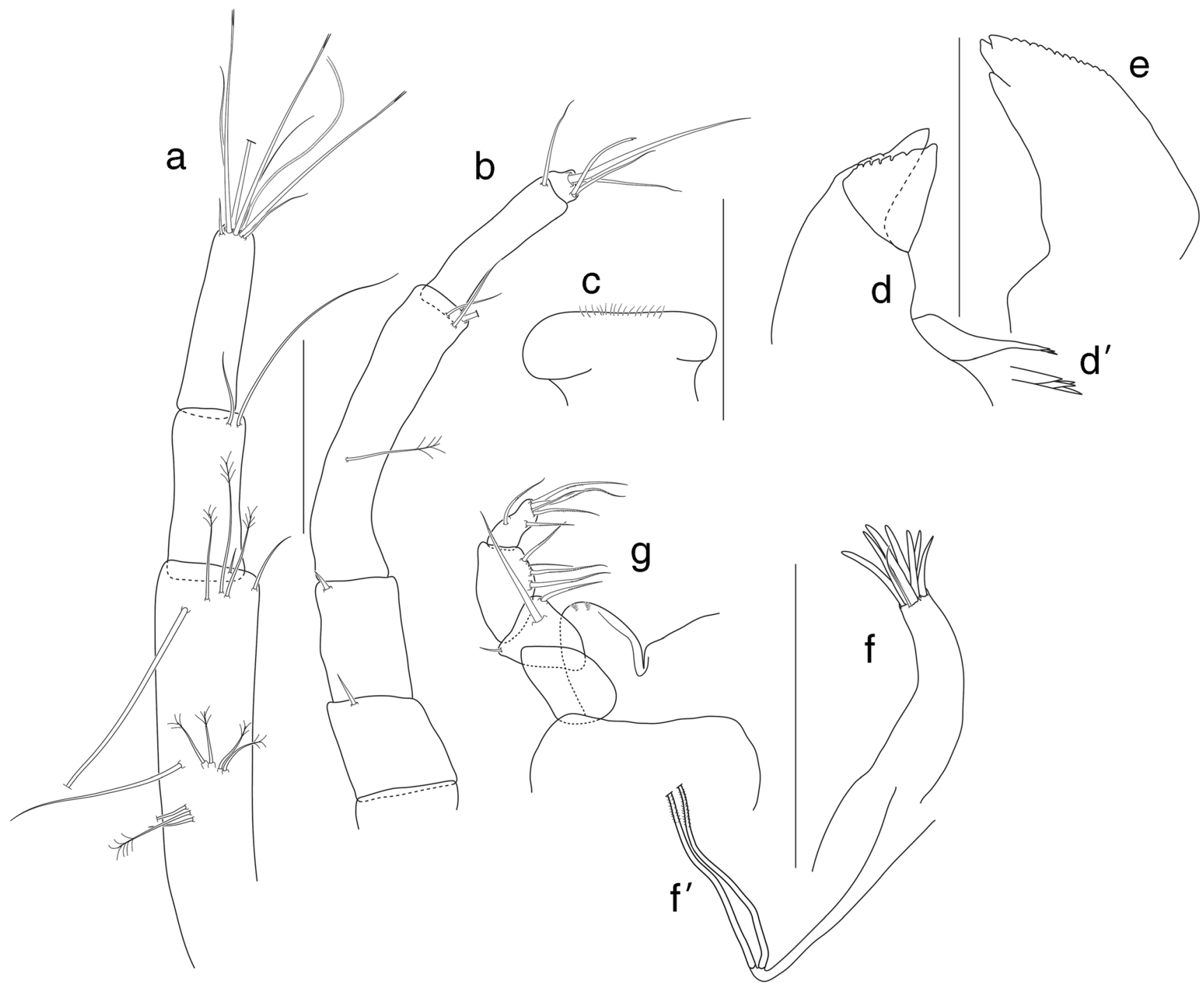

Fig. 16 Pseudotanais sigrunis sp. n. preparatory female. A antennule, B antenna, C labrum, D left mandible, D' molar of left mandible, E right mandible, F maxillule endite, F' maxillule palp, G maxilliped. Scale: $0.1 \mathrm{~mm}$ for A, B and 0.01 for C-F

simple setae; merus 1.5 times as long as wide, 0.5 times as long as carpus, with one distoventral seta; carpus 3.3 times as long as wide, 0.9 times as long as propodus, dorsal margin with microtrichiae, distodorsal sensory seta and distoventral small spine and blade-like spine (0.4 times as long as propodus); propodus 6 times as long as wide, with distal margin setose and dorsal margin with microtrichiae, short and long ventrodistal setae and long (as long as propodus) penicillate, distodorsally; dactylus 0.2 times as long as propodus, unguis 0.3 times as long as dactylus, combined 0.3 times as long as propodus.

Pereopod-5 (Fig. 14f) similar to pereopod-4.

Pereopod-6 (Fig. 14g) similar to pereopod-4, but propodus with additional longer seta.

Pleopod (Fig. 14i) endopod 4.6 times as long as wide, with six distal setae; exopod 3.2 times as long as wide, with eleven distal setae.
Uropod (Fig. 14h) basis naked; exopod 0.8 times as long as endopod, with two articles, article-1 0.8 times as long as article-2, with distal seta, article-2 with at two distal setae; endopod with two subequal articles, article-1 with one simple and penicillate distal setae, article- 2 with four long, two short simple setae and one plumose seta terminally (Table 4).

Distribution: Pseudotanais svavarssoni $\mathrm{sp} . \mathrm{n}$. was represented in Norwegian Sea, in the depth range 2172.6$2401.8 \mathrm{~m}$ (Fig. 7a).

Remarks: Pseudotanais svavarssoni $\mathrm{sp} . \mathrm{n}$. with characters such as (1) spines on antenna articles 2-3, (2) acuminate molar, (3) long distodorsal seta on pereopod-1 merus, and (4) elongated uropods, with exopod somewhat shorter than endopod, can be unequivocally regarded as representing the "affinis" group. It is distinguished from other members of the group by (1) relatively slender spines on antenna articles 2-3 (the spines are strong in P. affinis, P. scalpellum, and 
Fig. 17 Pseudotanais sigrunis sp. n., preparatory female. a Cheliped. b Pereopod-1. c Pereopod-2. d Pereopod-3. e Pereopod-4. f Pereopod-5. g Pereopod-6. h Uropod. i Pleopod. Scale: $0.1 \mathrm{~mm}$

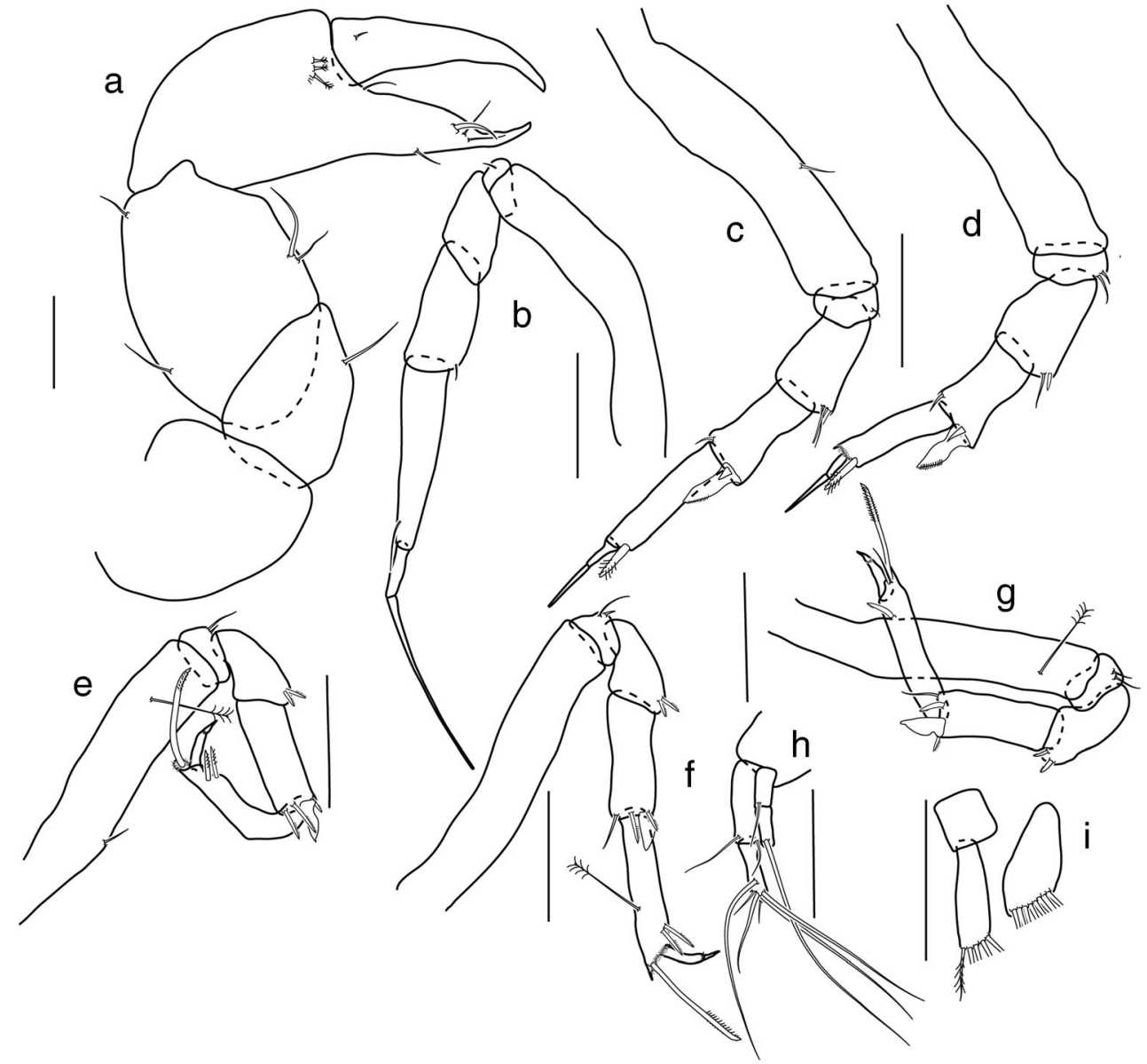

Pseudotanais sp. P), (2) the presence of two setae on merus of the pereopods 2-3 (the spine in P. affinis and P. scalpellum, and the spine and seta in Pseudotanais sp. $\mathrm{P}$ are relatively long), as well as a slender dactylus and unguis in the pereopods $4-6$ (see Table 5 ).

The history of the "affinis: group is quite convoluted (Bird and Holdich 1985, 1989a). The first species, Pseudotanais affinis Hansen, 1887, was described from Kara Sea; it was subsequently recognized, based on the Ingolf collection, in numerous locations, e.g., the Davis Strait, around Iceland, south of Jan Mayen, an East Greenland fjord (Hansen 1913; Fig. 2b). Morphological differences between the specimens studied by Hansen (1913) were considered the intraspecific variation, although the eurytopic distribution of the species, reported from both "warm" $\left(2.4-4.5{ }^{\circ} \mathrm{C}\right)$ and "cold" $(0.4$ $0.9^{\circ} \mathrm{C}$ ) areas over a relatively wide depth range (582 $-2196 \mathrm{~m}$ ) suggests a complex of (possibly) cryptic species. Later on, the distribution range of the species was extended to cover an area between off the British coasts down to the Bay of Biscay (Bird and Holdich, 1989b).

The wide distribution and interspecific morphological variability of pseudotanaids was addressed by Bird and Holdich, 1989a). Having conducted comprehensive morphological studies which involved re-examination of
Hansen's collection, they concluded that the species Sieg (1977) identified and illustrated as P. affinis was hardly a member of the "affinis" group on account of its wide mandible molar and the setae on antenna articles 2-3. As a result, they erected two new species: P. corollatus Bird and Holdich, 1989b to accommodate the former P. affinis from the Davis Strait (Hansen 1913), and P. denticulatus for the former $P$. affinis from off the west coast of Great Britain and the Bay of Biscay (Bird and Holdich, 1989a).

The presence of the wide mandible led Bird to assume that $P$. denticulatus and P. corollatus may come from the same group of species, the "denticulatus." Another species that could be assigned to the group is Pseudotanais sp. A (McLelland, 2008). Differences between the "affinis" and the "denticulatus" species-groups are listed in Table 5.

As emphasized by Bird and Holdich (1989b), we are far away from fully recognizing the complexity of the "affinis" species-group. Based on the existing knowledge, they provisionally assigned three other species to the group: P. spatula Bird and Holdich, 1989a; P. scalpellum Bird and Holdich, 1989b; and P. longispinus Bird and Holdich, 1989a. Although all those species are, most likely, phylogenetically closely related to the "affinis" group (Jakiel unpublished data), they may represent two separate evolutionary lines. The 


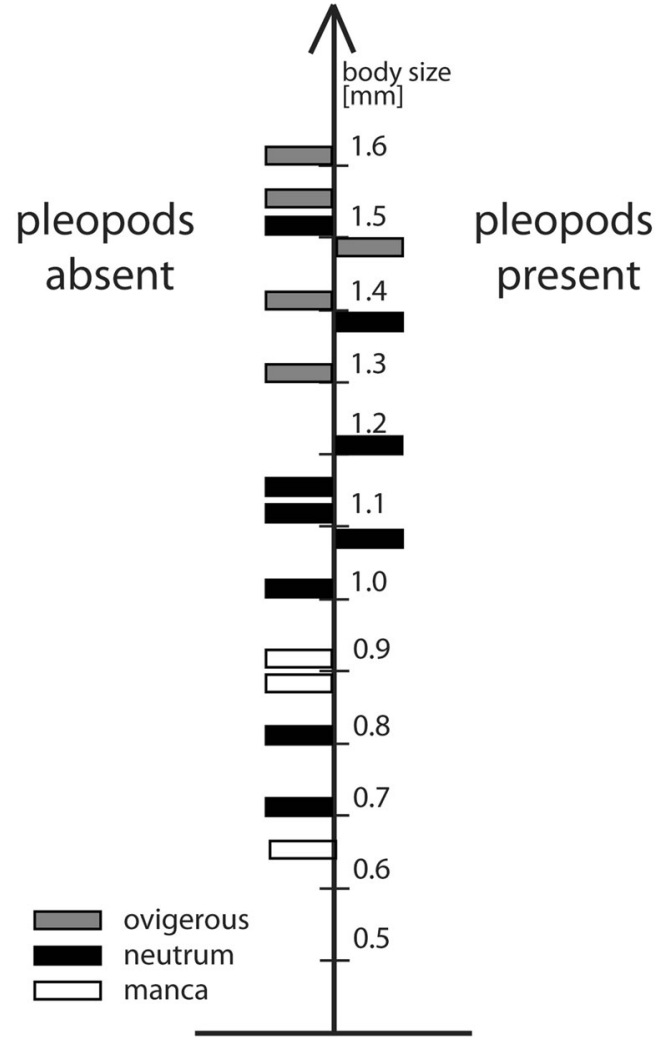

Fig. 18 Morphological variability of the occurrence of the pleopods in different life stages in Pseudotanaid sigrunis sp. n.

first (Pseudotanais longisetosus Sieg, 1977; P. longispinus Bird and Holdich, 1989a; P. nipponicus McLelland, 2007; P. spatula Bird and Holdich, 1989b; and Pseudotanais sp. O, McLelland, 2008) is defined by two autapomorphies: the presence of a long seta on the merus and carpus of pereopod-1 and a few setae on the pereopod 1-3 basis. Members of the other line show a long seta only on the merus of pereopod- 1 and few (if any) setae on the basis of pereopods 1-3. Further analysis of other Pseudotanais species with an acuminate mandible and the uropod exopod slightly shorter than the endopod support distinguishing still one more species-group, the "longisetosus." Differences between the "affinis" and "longisetosus" groups are listed in Table 5.

Pseudotanais svavarssoni species complex

Material examined: two neutri (ZMH K-54810), St. 871-4, $62^{\circ} 45.31^{\prime} \mathrm{N} 000^{\circ} 54.09^{\prime} \mathrm{W}$, depth $1562.7 \mathrm{~m}, \mathrm{GKG}, 26$ Jul 2013; two neutri, one juvenile male (ZMH K-54811), St.

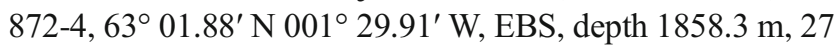
Jul 2013; manca (ZMH K-54812), St. 872-5, 63 01.80' N $001^{\circ} 27.05^{\prime} \mathrm{W}$, depth $1842 \mathrm{~m}, \mathrm{GKG}, 27$ Jul 2013; two neutri (ZMH K-54813), St. 873-2, 61 ${ }^{\circ} 46.63^{\prime} \mathrm{N} 003^{\circ} 52.38^{\prime} \mathrm{W}$, depth $835.1 \mathrm{~m}, \mathrm{GKG}, 28$ Jul 2013; juvenile male, St. 873-6, $61^{\circ} 46.52^{\prime} \mathrm{N} 003^{\circ} 52.38^{\prime} \mathrm{W}$, depth $833.7 \mathrm{~m}$, EBS, 28 Jul 2013; two neutri (ZMH K-54814), St. 879-2, 63 06.02' N 008 35.14' W, depth 505.9 m, SG, 31 Jul 2013; two neutri, one

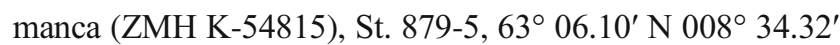
W, EBS, depth $510.9 \mathrm{~m}, 31$ Jul 2013; neutrum (ZMH K-54816), St. 880-2, $63^{\circ} 23.36^{\prime} \mathrm{N} 008^{\circ} 09.42^{\prime} \mathrm{W}$, depth 686 m, EBS, 31 Jul 2013; juvenile male, (ZMH K-54817), St. 881-4, $63^{\circ} 34.66^{\prime} \mathrm{N} 007^{\circ} 42.69^{\prime} \mathrm{W}$, depth $1043.6 \mathrm{~m}$, EBS, 01 Aug 2013; neutrum (ZMH K-54818), St. 881-6, 633 38.50' $\mathrm{N} 007^{\circ} 47.03^{\prime} \mathrm{W}$, depth $1073.4 \mathrm{~m}, \mathrm{VV}, 01$ Aug 2013; ovigerous female, (ZMH K-54819), St. 882-2, 63 25.01' N $010^{\circ} 58.80^{\prime} \mathrm{W}$, depth $441.4 \mathrm{~m}, \mathrm{VV}, 02$ Aug 2013; three neutri, four ovigerous females, two juvenile males, (ZMH K-54820), St. 882-5, $63^{\circ} 25.04^{\prime} \mathrm{N} 010^{\circ} 58.20^{\prime} \mathrm{W}, 440.5 \mathrm{~m}, \mathrm{EBS}, 02$ Aug 2013; neutrum, (ZMH K-54821), St. 963-1, 60 2.72' $\mathrm{N} 21^{\circ} 29.52^{\prime} \mathrm{W}-60^{\circ} 2.73^{\prime} \mathrm{N} 21^{\circ} 29.86^{\prime} \mathrm{W}$; depth $2746 \mathrm{~m}$, EBS, 29 Aug 2011; neutrum, (ZMH K-54822), St. 979-1, $60^{\circ}$ $20.87^{\prime} \mathrm{N} 18^{\circ} 8.52^{\prime} \mathrm{W}-60^{\circ} 20.72^{\prime} \mathrm{N} 18^{\circ} 8.60^{\prime} \mathrm{W}, 2568.8-2571$ $\mathrm{m}, \mathrm{EBS}, 30$ Aug 2011; three neutri, (ZMH K-54823), St. $1010-1,62^{\circ} 33.17^{\prime} \mathrm{N} 20^{\circ} 23.18^{\prime} \mathrm{W}-62^{\circ} 33.22^{\prime} \mathrm{N} 20^{\circ} 22.88^{\prime}$ W, 1383.3-1387.8 m, EBS, 02 Sep 2011; neutrum, (ZMH K-54824), St. $1019-1$, (62 ${ }^{\circ} 56.46^{\prime} \mathrm{N} 20^{\circ} 44.06^{\prime} \mathrm{W}-62^{\circ}$

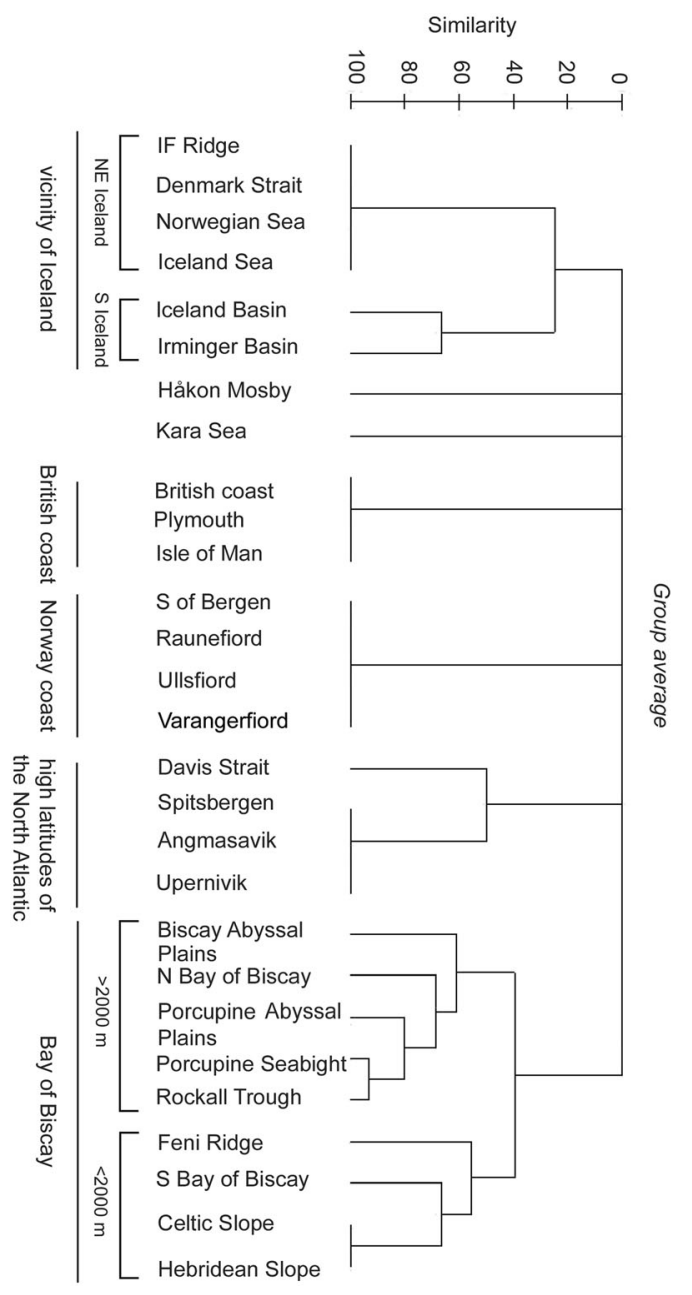

Fig. 19 Dendrogram of similarity (Bray Curtis, average linkage clustering method) of occurrence of Pseudotanaidae fauna in the North Atlantic based on both present study and literature data (see caption of Table 4) 


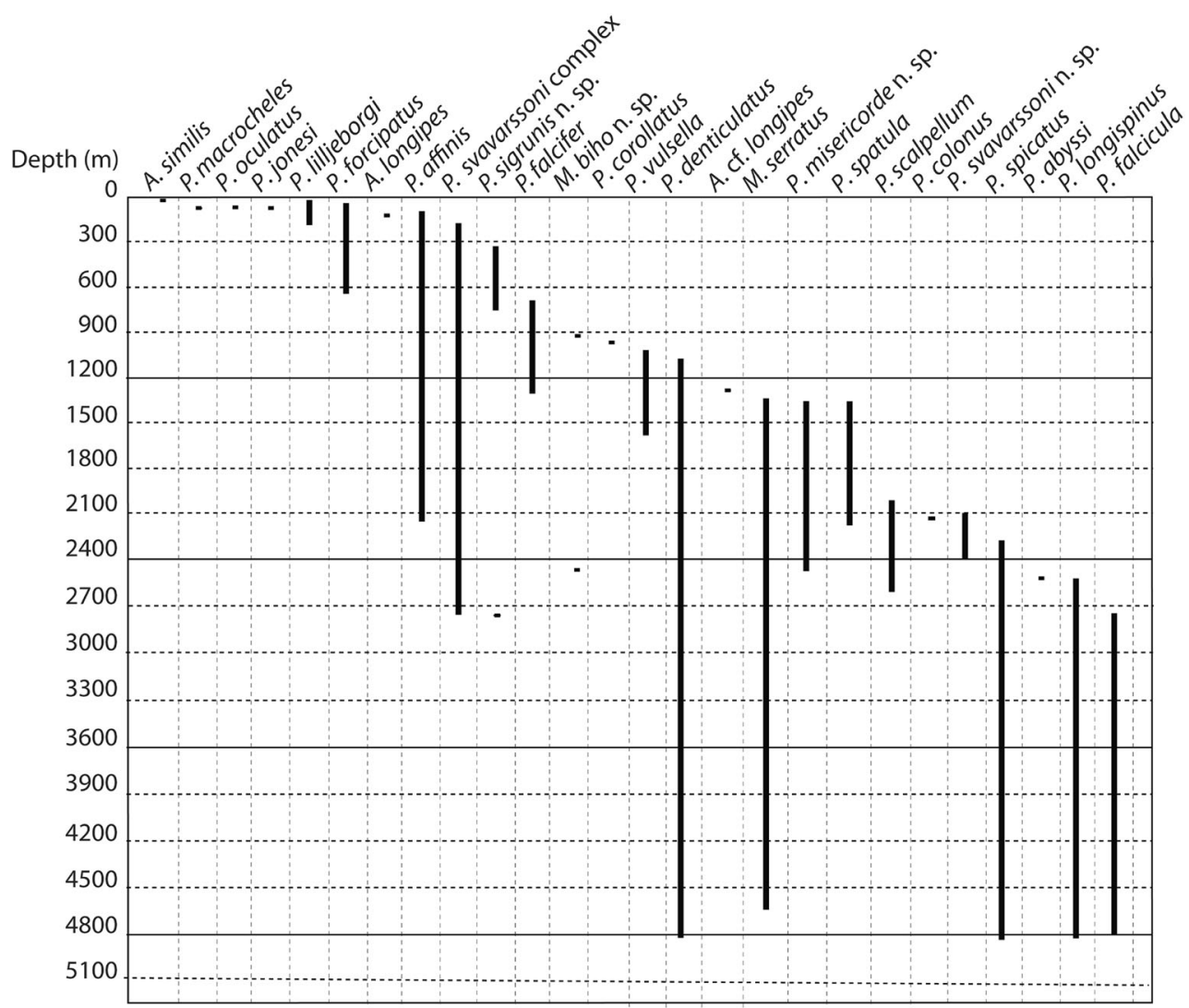

Fig. 20 Bathymetric distribution of the Pseudotanaidae species recorded in the N Atlantic from both the IceAGE collection and literature data. For literature data, see Table 4 caption

56.52' N 204 $43.77^{\prime} \mathrm{W}$, depth 916.1-909.4 m, EBS, 03 Sep 2011; 15 neutri, three juvenile males, (ZMH K-54825), St. $1043-1,63^{\circ} 55.53^{\prime} \mathrm{N} 25^{\circ} 57.54^{\prime} \mathrm{W}-63^{\circ} 55.62^{\prime} \mathrm{N} 25^{\circ} 57.36^{\prime}$ W, depth 214.9-216.5 m, EBS, 05 Sep 2011; neutrum, (ZMH K-54826), St. 1051-1, $61^{\circ} 37.40^{\prime} \mathrm{N} 31^{\circ} 22.11^{\prime} \mathrm{W}, 2547.5 \mathrm{~m}$, GKG, 07 Sep 2011; two neutri, (ZMH K-54827), St. 1054-1, $61^{\circ} 36.82^{\prime} \mathrm{N} 31^{\circ} 22.26^{\prime} \mathrm{W}-61^{\circ} 36.98^{\prime} \mathrm{N} 31^{\circ} 22.18^{\prime} \mathrm{W}$, 2545.7-2536.8 m, EBS, 07 Sep 2011; two neutri, (ZMH K-54828), St. $1072-1,63^{\circ} 0.97^{\prime} \mathrm{N} 28^{\circ} 3.35^{\prime} \mathrm{W}-63^{\circ} 1.10^{\prime} \mathrm{N}$ $28^{\circ} 3.15^{\prime} \mathrm{W}$, depth 1564.2-1567 m, EBS, 09 Sep 2011; neutrum, (ZMH K-54829), St. 1086-1, 63 $42.66^{\prime} \mathrm{N} 26^{\circ}$ $22.78^{\prime} \mathrm{W}-63^{\circ} 42.78^{\prime} \mathrm{N} 26^{\circ} 22.54^{\prime} \mathrm{W}$, depth 688.4-680.3 m, EBS, 09 Sep 2011; neutrum, (ZMH K-54830), St. 1129-1, $67^{\circ}$ $38.77^{\prime} \mathrm{N} 26^{\circ} 44.78^{\prime} \mathrm{W}$, depth $320.6 \mathrm{~m}$, GKG, 14 Sep 2011; three neutri, (ZMH K-54831), St. $1132-1,67^{\circ} 38.48^{\prime} \mathrm{N} 026^{\circ}$ 45.28' W, 318.1 m, EBS, 14 Sep 2011; neutrum, ovigerous female, (ZMH K-54832), St. 1136-1, $67^{\circ} 38.06^{\prime}$ N 26 46,19' $\mathrm{W}-67^{\circ} 37.96^{\prime} \mathrm{N} 26^{\circ} 46.42^{\prime} \mathrm{W}$, depth $315.9 \mathrm{~m}$, EBS, 14 Sep 2011; neutrum, (ZMH K-54833), St. 1141-1, $67^{\circ} 50.22^{\prime}$ N $23^{\circ}$ 42.11' W, depth $1241.6 \mathrm{~m}, \mathrm{GKG}, 15$ Sep 2011; four neutri, juvenile male, (ZMH K-54834), St. 1148-1, $67^{\circ} 50.79^{\prime} \mathrm{N} 023^{\circ}$ 41.76' W, depth 1248.8 m, EBS, 15 Sep 2011; neutrum male, manca, (ZMH K-54835), St. $1178-1,67^{\circ} 38.72^{\prime} \mathrm{N} 12^{\circ} 10.10^{\prime}$ W, depth 1818.9 m, GKG, 20 Sep 2011; six neutri, two ovigerous females, (ZMH K-54836), St. 1184-1, 67 38.63' $\mathrm{N} 012^{\circ} 09.72^{\prime} \mathrm{W}$, depth $1819.3 \mathrm{~m}$, EBS, 20 Sep 2011; three neutri females, two juvenile males, manca, (ZMH K-54837), St. $1188-1,67^{\circ} 4.32^{\prime} \mathrm{N} 13^{\circ} 0.89^{\prime} \mathrm{W}$, depth $1580.6 \mathrm{~m}, \mathrm{GKG}$, 21 Sep 2011; seven neutri, two juveniles male $(\mathrm{ZMH}$ K-54838), St. $1212-1,66^{\circ} 32.63^{\prime} \mathrm{N} 012^{\circ} 52.48^{\prime} \mathrm{W}$, depth $317.2 \mathrm{~m}$, EBS, 22 Sep 2011; five neutri, juvenile male, (ZMH K-54839), St. $1216-1,66^{\circ} 18.06^{\prime} \mathrm{N} 12^{\circ} 22.38^{\prime} \mathrm{W}$, 730.8 m, GKG, 22 Sep 2011; 5 neutri, (ZMH K-54840), $1219-1,66^{\circ} 17.34^{\prime} \mathrm{N} 012^{\circ} 20.82^{\prime} \mathrm{W}$, depth $579.1 \mathrm{~m}$, EBS, 22 Sep 2011.

Diagnosis: carapace, pereonites, and pleonites combined length $0.7-1.7 \mathrm{~mm}$; cheliped carpus $1.3-2.0$ times as long as wide, propodus 1.3-2.0 times as long as wide; pereopod-1 propodus 1.7-2.6 times as long as carpus, propodus $0.7-1.2$ times as long as combined length of dactylus and unguis; pereopod-3 propodus 1.1-1.6 times as long as blade-like spine; pereopod-6 propodus 1.4-4.7 times as long as distal carpal seta.

Distribution: P. svavarssoni species complex is widely represented in the studied area and in the widest depth range (214-2746 m). It occurs in all investigated regions: IcelandFaroe Ridge, Iceland Basin, Irminger Basin, Denmark Strait Norwegian Channel, and Norwegian Sea (Fig. 7a). 
Pseudotanais sigrunis sp. $\mathrm{n}$.

Figs 15, 16, and 17

Material examined: Holotype neutrum (ZMH K-54841); St. 1216-1, $66^{\circ} 1.06^{\prime} \mathrm{N} 12^{\circ} 22.38^{\prime} \mathrm{W}$, depth $730.8 \mathrm{~m}, 22$ Sep 2011.

Two ovigerous female, (ZMH K-54842), St. 882-2, $63^{\circ}$ $25.01^{\prime} \mathrm{N} 010^{\circ} 58.80^{\prime} \mathrm{W}$, depth $441.4 \mathrm{~m}, 02$ Aug 2013; one neutrum, ovigerous female, (ZMH K-54843), St. 882-5, $63^{\circ}$ 25.04' ${ }^{\prime}$ 010 58.20' W, depth 440.5 m, EBS02 Aug 2013; manca (ZMH K-54844), St. 880-3, 63 24.79' N 008 $11.63^{\prime}$ W, depth $688.1 \mathrm{~m}, \mathrm{GKG}, 31 \mathrm{Jul} 2013$; neutrum (ZMH K-54845), St. 963-1, 60².72' N $21^{\circ} 29.52^{\prime} \mathrm{W}-60^{\circ} 2.73^{\prime} \mathrm{N}$ $21^{\circ} 29.86^{\prime} \mathrm{W}$, depth 2746.4-2746 m, EBS, 29 Aug 2011; neutrum, (ZMH K-54846), St. $1116-1,67^{\circ} 12.82^{\prime} \mathrm{N} 26^{\circ}$ $16.31^{\prime} \mathrm{W}$, depth $683.1 \mathrm{~m}, \mathrm{GKG}, 14$ Sep 2011; three neutri, ovigerous female, manca, (ZMH K-54847), St. 1212-1, $66^{\circ}$ 32.63' N $012^{\circ} 52.48^{\prime} \mathrm{W}$, depth $317.2 \mathrm{~m}$, EBS, 22 Sep. 2011; two neutri, manca, (ZMH K-54848), St. 1216-1, 66 $18.06^{\prime} \mathrm{N}$ $12^{\circ} 22.38^{\prime} \mathrm{W}$, depth $730.8 \mathrm{~m}, \mathrm{GKG}, 22 \mathrm{Sep} 11$; neutrum, ovigerous female, (ZMH K-54849), St. 1219-1, 66 17.34' N 012 20.82' W, depth 579.1 m, EBS, 22 Sep 2011.

Diagnosis: Eyes absent. Antennule article-1 four times as long as wide. Antenna article-2 with seta, article-3 with spine. Mandible molar acuminate with four spines. Maxilliped endites simple. Cheliped robust, chela not forcipate; carpus 1.6 times as long as wide; unguis and dactylus distal spines inside bent. Pereopods 2-6 carpal blade-like spine well developed. Uropod exopod two articulated, as long as endopod article-1.

Etymology: The species named after Sigrún Haraldsdóttir, a great fellow during cruise IceAGE, who tirelessly helped in sorting of the benthic samples onboard.

Description of neutrum: Body (Fig. 15) more than three times as long as broad. Cephalothorax $22 \%$ of total body length subtriangular, with two pairs of lateral simple seta. Eyes absent. Pereon 55\% of total body length. Pereonite-1 0.6 times as long as pereonite-2; pereonite-2 0.7 times as long as pereonite-3; pereonite-3 0.6 times as long as pereonite-4; pereonites-4 0.7 times as long as pereonites-5; pereonites-5 twice as long as pereonite-6; pereonites $0.1,0.2,0.3,0.5$, 0.6 , and 0.4 times as long as broad respectively (measurements for the holotype); pereonites 1-5 each with a pair of simple lateral setae. Pleonites $15 \%$ of total length, as long as pereonite-5. Pleotelson $8 \%$ of total length, as long as three pleonites combined length, with two pairs of distal seta.

Antennule (Fig. 16a) article-1 3.7 times as long as wide, with outer medial and distal tufts penicillate (3-5) and simple (1-3) setae. Article-2 2.3 times as long as wide and 0.4 times as long as article-1 with short and long outer distal setae; article-3 as long as article-2, with one aestetasc, four simple, three distally trifurcate and one broken seta.

Antenna (Fig. 16b) aricle-1 fussed with body, article-2 as long as wide with one thin spine, article-3 1.4 times as long as wide, and 1.2 times as long as article-2, with small distal spine; article-4 four times as long as wide and 2.5 times as long as article-3, with one midlength penicillate seta and three distal setae (one broken); article-5 4.2 times as long as wide and 0.5 times as long as article-4, with one distal seta; article-6 short, with three simple and one bifurcated distal setae.

Mouthparts: Labrum hood-shaped, weakly setose (Fig. 16c); left mandible (Fig. 16d) incisor margin weakly serrated, lacinia mobilis large and irregularly serrated; molar acuminate with four distal spines (Fig. 16d'). Right mandible (Fig. 16e) with regularly serrated incisor, lacinia mobilis fussed to a small process; molar not seen. Maxillule (Fig. 16f) tipped with seven spines and one seta; endite (Fig. 16f') with two distal setae. Labium not observed. Maxilliped (Fig. 16g) endites distally separated, simple, with microtrichiae in distal corners; palp article-1 naked, article-2 with two inner setae (short and log) and one outer seta; article3 with four inner setae, article-4 with five simple inner and distal setae and one outer seta. Epignath not seen.

Cheliped (Fig. 17a) basis 0.9 times as long as broad; merus triangular with midventral seta; carpus elliptical, 1.5 times as long as wide, with two midventral setae and subproximal and distal setae dorsally; chela not-forcipate, propodus (palm) 1.7 times as long as wide, almost as long as fixed finger with two ventral seta and row of three serrated setae on inner side; fixed finger with three setae on cutting edge and one simple seta in near dactylus insertion; dactylus with dorsoproximal seta.

Pereopod-1 (Fig. 17b) basis 6.1 times as long as broad; ischium with simple seta; merus 1.5 times as long as wide, 0.7 times as long as carpus, naked; carpus 2.2 times as long as wide, 0.6 times as long as propodus, with one fine distodorsal seta; propodus 5.8 times as long as wide, with distoventral seta; dactylus 0.3 times as long as propodus, unguis four times as long as dactylus; unguis and dactylus combined 1.3 times as long as propodus.

Pereopod-2 (Fig. 17c) basis 5.4 times as long as wide with middle simple seta; ischium with simple seta; merus 2.1 times as long as wide, 1.1 times as long as carpus, with simple seta and spine distoventrally; carpus 2.4 times as long as wide, 0.7 times as long as propodus with blade-like spine 0.4 times as long as propodus, one distodorsal seta and short distoventral spine; propodus five times as long as wide, with serrated distal spine; dactylus 0.2 times as long as propodus, unguis twice as long as dactylus, dactylus and unguis combined 0.6 times as long as propodus.

Pereopod-3 (Fig. 17d) similar to pereopod-2, but merus with short spine and seta distoventrally; propodus three times as long as wide.

Pereopod-4 (Fig. 17e) basis 5.1 times as long as wide, with one simple seta midlength and one penicillate seta subdistally; ischium with short and long setae; merus 1.6 times as long as wide, 0.6 times as long as carpus, with two serrated distoventral setae; carpus 2.8 times as long as wide and 0.9 times as long as propodus, with blade-like spine 0.3 times as 
long as propodus and three serrated spines distally; propodus 5.7 times as long as wide, with two distoventral serrated spines and dorsodistal serrated seta; dactylus 0.3 times as long as propodus, unguis 0.1 times as long as propodus, dactylus and unguis combined 0.3 times as long as propodus.

Pereopod-5 (Fig. 17f) similar to pereopod-4; propodus five times as long as wide, with one distodorsal penicillate seta.

Pereopod-6 (Fig. 17g) similar to pereopod-4; but propodus with one additional simple seta distally.

Pleopoda (Fig. 17i) basal article as long as wide, 3.5 times as long as wide, with five distal setae; exopod 1.9 times as long as wide, with eight distal setae.

Uropod (Fig. 17h) basis naked; exopod 0.6 times as long as endopod, with two articles; article-1 times as long as article-2 with one distal seta; article-2 with two setae (one broken); endopod two articles, article-1 with two distal setae; article-2 with two short and four long distal setae.

Distribution: P. sigrunis sp. $\mathrm{n}$. was well represented in IceAGE material. It was recorded at Iceland Faroe Ridge, in Norwegian Channel, Iceland Basin, Denmark Strait, and Norwegian Sea (Fig. 7b) at the depth range from 317 to $731 \mathrm{~m}$ and $2746 \mathrm{~m}$.

\section{Morphology variables}

Some of the specimens of $P$. sigrunis sp. n. had fully developed pleopods, while the others missed those appendages (4 with and 13 without pleopods). This presence/absence of the pleopods was irrespective to locality, depth, body size, and, in some cases, also to the life stage (Fig. 18), although all studied mancas (0.6 $-0.9 \mathrm{~mm}$ ) apparently missed the pleopods. Pseudotanais sigrunis $\mathrm{sp}$. n. was a series of just 17 , widely distributed specimens, what hampers further analysis and any reliable conclusion. If the studied individuals are really conspecific, we can hypothesize the presence and the absence of the pleopods can be rationalized by presence in the life-history a dispersal stage.

Remarks: P. sigrunis sp. $\mathrm{n}$. with a robust cheliped, acuminate mandible molar, and short, bi-articulated exopod on the uropods is the most similar to Pseudotanais lilljeborgi Sars, 1882. Two other species with also an acuminate molar and a regular (non-forcipate) chela (P. colonus Bird and Holdich, $1989 \mathrm{~b}$ and P. falcifer Błażewicz-Paszkowycz and Bamber, 2011) show a non-articulated exopod on the uropods.

Pseudotanais lilljeborgi Sars, 1882 is a Pseudotanais with a wide geographic distribution (Fig. 2b) and numerous records in the literature (e.g., Sars 1896; Hansen 1913; Greve 1965a, b, c; Stephensen 1937; Just 1970; Bird and Holdich, 1989a), all records being confined to a relatively narrow depth range (139$536 \mathrm{~m}$ ). The species was described by Sars (1882) based on the type material from Varangerfjord (northern part of Norway) and diagnosed as a non-forcipate member of the genus with eyes and a relatively short exopod on the uropod (not longer than the proximal article of the endopod), the uropod endopod proximal article being longer than the distal one. Moreover, the species shows long setae on articles 2-3 of the antenna.

Sieg (1977) redescribed P. lilljeborgi using the Ingolf material collected off Iceland and Jan Mayen Island by Hansen (1913); he disregarded Hansen's note that the "Icelandic" specimens lacked eyes and their carapace shape differed from that of the "Norwegian" individuals (Hansen 1913, p. 27). In addition, the P. lilljeborgi studied by Sieg (1977) showed short setae on the antenna articles 2 and 3, and the exopod uropod somewhat longer than the endopod proximal article, while they were apparently long in the type specimens.

The newly described Pseudotanais sigrunis sp. n. shows setae on the antenna articles 2-3 to be as short as those in $P$. lilljeborgi studied by Sieg (1977), the exopod uropod being somewhat longer than the endopod proximal article. Therefore, we assume that the part of the Ingolf collection studied by Sieg (1977) is conspecific with P. sigrunis.

It is important to emphasize that all except one specimens were found in relatively shallow areas (317-731 m) in nearly all the basins around Iceland, a single individual only being collected at a deeper station (2746 m, the Icelandic Basin). Morphological analyses failed to reveal differences between the "shallow" and the "deep" individuals. Nevertheless, we anticipate that molecular studies involving a larger collection of specimens should show whether (1) the "shallow-water" and the "deep-water" populations of the species are conspecific rather than forming a complex of cryptic species, and (2) other records of $P$. lilljeborgi (e.g., from off the northern part of Norway: vicinity of Kvalsund (Greve 1965a, c), Barents Sea (Strapper unpublished data), and East Greenland (Hansen 1913)) belong to the only one species.

\section{Discussion}

The Pseudotanaidae are currently represented by 51 nominal species known worldwide (WoRMS 2018). In the North Atlantic, the number of nominal pseudotanaid species known at present is, together with the new species described in this paper, 25 (Table 4). The IceAGE collection represented by 323 specimens was dominated by Pseudotanais svavarssoni $\mathrm{sp} . \mathrm{n}$. which accounted for $57 \%$ of the specimens examined, followed by Pseudotanais sigrunis sp. n., Pseudotanais misericorde sp. n., Mystriocentrus biho sp. n., and Akanthinotanais cf. longipes, which made up 5.5, 1.8, 1.2, and $0.3 \%$ of all the identified specimens, respectively. Because of poor preservation condition, five specimens from the collection we studied could not be identified to the species level (Table 2).

Most of those taxa have a limited zoogeographical range (i.e., one, relatively well-defined basin) and a distinct bathymetric range (Fig. 19). The Bray-Curtis similarity-based 
cluster analysis separated the different a priori designated areas into groups based on the pseudotanaid faunas:

- Off the British coast: P. corollatus and P. jonesi

- Off the Norwegian coast: P. macrocheles

- High latitudes of the North Atlantic: P. oculatus

- The Bay of Biscay and the Porcupine Abyssal Plain: $P$. abyssi, $P$. colonus, $P$. denticulatus, $P$. falcicula, $P$. longispinosus, $P$. scalpellum, P. serratus, A. similis, $P$. spatula, P. spicatus, and P. vulsella

- Off Iceland: north-P. svavarssoni sp. n.; south-A. longipes, M. biho sp. n., P. misericorde sp. n., P. svavarssoni complex

A separate group in the dendrogram was made up by P. falcifer known from mud volcanoes off Norway (Błażewicz-Paszkowycz and Bamber 2011). In addition, the Kara Sea with the original locality of $P$. affinis produced a separate branch in the dendrogram. Three species, namely $P$. forcipatus, $P$. affinis, and $P$. lilljeborgi, are particularly widely distributed, their range extending from the high Arctic (the Barents Sea) to the British coast of the North Sea (e.g., P. forcipatus) or from Novaya Zemlya to the coasts of Norway and Iceland to the west coast of Greenland ( $P$. affinis and P. lilljeborgi) (Table 4).

The bathymetric range of $\mathrm{N}$ Atlantic pseudotanaids extends from the upper shelf down to $4800 \mathrm{~m}$ (Fig. 20), few of them showing a narrow range (e.g., A. similis, $P$. macrocheles, $P$. oculatus, $P$. jonesi, $P$. corollatus, $P$. colonus, $P$. abyssi). Unsurprisingly, all of those species have very narrow zoogeographical distribution and they are often restricted to the type locality (Fig. 2). An exception is $P$. macrocheles that occurs only in Norwegian fjords (Fig. 2d). A few other pseudotanaids recorded in the North Atlantic show a depth range extending from some hundred meters up to $2500 \mathrm{~m}$ (e.g., P. sigrunis sp.n., 317-731 m; P. svavarssoni sp. n., 2172-2401 m; M. biho sp. n.; 913$2537 \mathrm{~m}$; P. scalpellum, 2081-2634 m; P. falcifer, 722 $1263 \mathrm{~m} ;$ P. spatula, 1400-2200 m; P. vulsella, 1028$1640 \mathrm{~m}$; and P. misericorde, 1385, 1621, $2537 \mathrm{~m}$ ) and have a relatively narrow zoogeographical distribution (Figs. 2 and 7). Five species (P. longispinus, $P$. spicatus, $P$. falcicula, $M$. serratus, and $P$. denticulatus) spans their bathymetric range over $3000 \mathrm{~m}$, although the distribution is relatively narrow (Fig. 20). Two of them, P. denticulatus and $P$. serratus, show the widest depth range (around 3700 and $3100 \mathrm{~m}$, respectively). Quite a wide depth range has been also found in the $P$. svavarssoni complex $(2500 \mathrm{~m})$ and $P$. affinis $(1700 \mathrm{~m})$, accompanied by a wide zoogeographical range (Fig. 7), in contrast to $P$. lilljeborgi and $P$. forcipatus, both showing shallower depth ranges $(<$ $500 \mathrm{~m}$ ), but wide zoogeographical distributions (Fig. 2b).

\section{Conclusion}

In the IceAGE collection made in waters surrounding Iceland (Irminger Basin, Iceland Basin, Norwegian Sea, Denmark Strait, Iceland-Faroe Ridge, and Norwegian Channel), five species of pseudotanaids were identified; four of them were new for science (Mystriocentrus biho sp. n., P. misericorde sp. n., P. sigrunis sp. n., and P. svavarssoni sp. n.). Apart from species new to the knowledge, Akanthinotanais cf. longipes was collected from close place to type locality A. longipes Hansen, 1913 that is known only from that original location. One species that is probably complex of closely related species morphologically was very similar with $P$. svavarssoni $\mathrm{sp}$. $\mathrm{n}$. The morphometric approach and analysis highlighted significant differences between specimens collected in northern and southern Icelandic basins; distinct differences were also apparent between specimens collected from shallow and deep waters. Molecular approach is required to confirm our findings. Pseudotanaidae of Iceland are currently represented by seven nominal species.

Distinguished in the analysis, zoogeographical regions are represented by distinct pseudotanaid fauna. Our results stay in contrast to the earlier observation for bivalves (Dijkstra et al. 2009) or munnopsids (Schnurr et al. 2014). The wide distribution of these isopods in the North Atlantic and marine basins are rationalized by their efficient swimming abilities and potentially high ecological plasticity.

Considering a restricted dispersal ability of pseudotanaids, the North Atlantic could be divided into several zones, where distinct species, or discrete group of species, are noted (see Fig. 19). For example, some taxa are known only for the Bay of Biscay while P. oculatus were noted in high latitudes in the North Atlantic, but P. macrocheles was collected from fiords along Norway coast.

Four of the pseudotanaid species in the North Atlantic are widely distributed. P. affinis, P. macrocheles, P. lilljeborgi, and $P$. forcipatus were noted in various marine basisn located around Iceland, Norway, and Greenland. Those records need to be re-examined, and it is highly probable that they represent complex of sister (or cryptic) species.

Acknowledgments We appreciate Captain Michael Schneider, the crew of R/V Meteor and Klaus Ricke with his crew of R/V Poseidon, the scientist participating in the IceAGE programs as well as pickers and sorters for their valuable help on and off board. We are thankful to Kelly Merrlin for language editions. We are grateful to two anonymous reviewers for comments and critiques that helped to improve this article. This study was funded by the National Science Centre of Poland (grant number UMO-2014/13/B/NZ8/04702).

Funding This study was funded by Polish National Science Centre grant (UMO-2014/13/B/NZ8/04702).

\section{Compliance with ethical standards}

Conflict of interest The authors declare that they have no conflict of interest. 
Ethical approval All applicable international, national, and/or institutional guidelines for the care and use of animals were followed by the authors.

Field study Permits and approval of field or observational studies are not applicable for authors.

Open Access This article is distributed under the terms of the Creative Commons Attribution 4.0 International License (http:// creativecommons.org/licenses/by/4.0/), which permits unrestricted use, distribution, and reproduction in any medium, provided you give appropriate credit to the original author(s) and the source, provide a link to the Creative Commons license, and indicate if changes were made.

\section{References}

Astthorsson OS, Gislason A, Jonsson S (2007) Climate variability and the Icelandic marine ecosystem. Deep Sea Res II 54:2456-2477

Bamber RN (2005) The Tanaidaceans (Arthropoda: Crustacea: Peracarida: Tanaidacea) of Esperance, Western Australia, Australia. In: Wells FE, Walker DI, Kendrick GA (eds) The marine Flora and Fauna of Esperance, Western Australia: proceedings of the twelfth international marine biological workshop. Western Australia museum, Perth, pp 613-728

Bamber RN (2012) Littoral Tanaidacea (Crustacea: Peracarida) from Macaronesia: allopatry and provenance in recent habitats. J Mar Biol Assoc UK:1-22. https://doi.org/10.1017/S0025315412000252

Bird GJ (1999) A new species of Pseudotanais (Crustacea, Tanaidacea) from cold seeps in the deep Caribbean, collected by the French submersible Nautile. Zoosystema 21:445-451

Bird GJ, Holdich DM (1985) A remarkable tubicolous tanaid (Crustacea: Tanaidacea) from the Rockall trough. J Mar Biol Assoc U K 65: 563-572

Bird GJ, Holdich DM (1989a) Tanaidacea (Crustacea) of the north-East Atlantic: the subfamily Pseudotanainae (Pseudotanaidae) and the family Nototanaidae. Zool J Lin Soc Lond 97:233-298

Bird GJ, Holdich DM (1989b) Recolonisation of artificial sediments in the deep Bay of Biscay by Tanaidaceans (Crustacea: Peracarida), with a description of a new species of Pseudotanais. J Mar Biol Assoc UK 69:307-317

Bird GJ, Larsen K (2009) Tanaidacean phylogeny: the second step. The basal paratanaoidean families. Arthropod Syst Phylogeny 67:137158

Błażewicz-Paszkowycz M, Bamber RN (2011) Tanaidomorph Tanaidacea (Crustacea: Peracarida) from mud-volcano and seep sites on the Norwegian margin. Zootaxa 3061:1-35

Błażewicz-Paszkowycz M, Bamber RN, Anderson G (2012) Diversity of Tanaidacea(Crustacea: Peracarida) in the world's oceans - how far have we come? PLoS One 7:e33068

Błażewicz-Paszkowycz M, Bamber RN, Jóźwiak P (2013) Tanaidaceans (Crustacea: Peracarida) from the SoJaBio joint expedition in slope and deeper waters in the sea of Japan. Deep Sea Res II 86:181-213

Błażewicz-Paszkowycz M, Jennings RM, Jeskulke K, Brix S (2014) Discovery of swimming males of Paratanaoidea (Tanaidacea). Pol Polar Res 35:415-453

Brix S (2011) A report from the IceAGE Expedition. http:/Www.Ifm. Zmaw.De/Fileadmin/Files/Leitstelle/Meteor/M85/M85-3-Scr.Pdf

Brix S, Svavarsson J (2010) Distribution and diversity of desmosomatid and nannoniscid isopods (Crustacea) on the Greenland-IcelandFaeroe ridge. Polar Biol 33:515-530. https://doi.org/10.1007/ S00300-009-0729-8
Brix S, Svavarsson J, Leese F (2014) A multi-gene analysis reveals multiple highly divergent lineages of the isopod Chelator Insignis (Hansen, 1916) south of Iceland. Pol Polar Res 35:225-242

Bruce JR, Colman JS and Jones NS (1963) Marine Fauna of the Isle of Man. Liverpool University Press, Liverpool, pp 307-307

Clarke K, Gorley R (2006) PRIMER v6: User manual/tutorial, PRIMERE. Plymouth

Coleman CO (2003) Digital inking: how to make perfect line drawings on computers. Org Divers Evolv http://Senckenberg.De/Odes/03-14. Htm, 1-14

Delamare-Deboutteville C (1960) Biologie des Eaux Souterraines Littorales et Continentales. Hermann, Paris pp 740

Delamare-Deboutteville CS Gerlach, Siewing RS (1955) Recherches sur la faune des eaux souterraines littorales du Golfe de Gascogne. Littoral des Landes. Vie Milieu 5:373-407

Dijkstra HH, Warén A, Gudmundsson G (2009) Pectinoidea (Mollusca: Bivalvia) from Iceland. Mar Biol Res 5:207-243

Dinter W (2001) Biogeography of the OSPAR maritime area. A synopsis and synthesis of biogeographical distribution patterns described for the north-east Atlantic. Federal Agency for Nature Conservation, Bonn

Drumm D, Bird G (2016) New deep-sea Paratanaoidea (Crustacea: Peracarida: Tanaidacea) from the northeastern Gulf of Mexico. Zootaxa 4154:389-414. https://doi.org/10.11646/Zootaxa.4154.4.2

Gislason A, Astthorsson OS (2004) Distribution pattern of zooplankton around Iceland in spring. Sarsia 20:85-94

Greve L (1965a) The biology of some Tanaidacea from Raunefjorden, western Norway. Sarsia 20:43-54

Greve L (1965b) Tanaidacea from Trondheimsfjorden. Det Kongelige Norske Videnskabers Selskabs Forhandlinger 38:140-143

Greve L (1965c) New records of some Tanaidacea (Crustacea) from the vicinity of Tromsö. Astarte 27:2-6

Hansen HJ (1887) Oversigt over de paa dijmpha-togtet indsamlede krebsdyr. Dijmphna Togtets Zool Bot Udbytte, Kopenhagen, pp 183-286

Hansen HJ (1913) Crustacea, malacostraca. II. IV. The order Tanaidacea. Danish Ingolf. Expedition 3:1-145

Hansen B, Osterhus S (2000) North Atlantic-Nordic seas exchanges. Prog Oceanogr 45:109-208

Holdich DM, Bird GJ (1986) A preliminary report on 'Dikonophoran' tanaidaceans (Crustacea). In: Laubier L, Monniot C (eds) Peuplements profonds du Golfe de Gascogne. Centre National De Tri D'oceanographie Biologique. Centob Ifremer, Brest, pp 441-447

Holdich DM, Jones JA (1983) The distribution and ecology of British shallow-water tanaid crustaceans (Peracarida, Tanaidacea). J Nat Hist 17:157-183

Jochumsen K, Schnurr SM, Quadfasel D (2016) Bottom temperature and salinity distribution and its variability around Iceland. Deep Sea Res 111:79-90

Just J (1970) Decapoda, Mysidacea, Isopoda, and Tanaidacea from Jørgen Brønlund Fjord, North Greenland. Meddelelser om Grønland udgivne af Kommissionen for Videnskabelige Undersøgelser i Grønland 184(9):1-32

Khodami S, Martinez Arbizu P, Stöhr S, Laakmann S (2014) Molecular species delimitation of Icelandic brittle stars (Echinodermata: Ophiuridea) pol. Polar Res 35:243-260

Larsen K (2005) Deep-Sea Tanaidacea (Peracarida) from the Gulf of Mexico. Crustaceana Monogr 5:1-381

Larsen K (2012) Tanaidacea (Peracarida) from Macaronesia I. The deepwater fauna off the Selvagen Islands, Portugal. Crustaceana 85:571589

Lilljeborg W (1864) Bidrag till kännedomen om de inom sverige och norrige förekommande Crustaceer af isopodernas underordning och tanaidernas familj. Inbjudningsskrifter Universitet i Uppsala, Uppsala. PAGES

Logemann K, Ólafsson J, Snorrason Á, Valdimarsson H, Andmarteinsdóttir G (2013) The circulation of Icelandic waters - a modelling study. Ocean Sci 9:931-955 
Malmberg SA (2004) The Iceland Basin-Topography and Oceanographic Features. Hafrannsóknir, No. 109, Reykjavík 2004: pp41.

Malmberg S, Valdimarsson H (2003) Hydrographic conditions in Icelandic waters, 1990-1999. In Ices mar Sc 219:50-60

McLelland JC (2007) Family Pseudotanaidae Sieg, 1976. In: Larsen K \& Shimomura M. (Eds) 2007. Tanaidacea (Crustacea: Peracarida) from Japan III. The deep trenches; the Kurile-Kamchatka Trench and Japan Trench. Zootaxa 1599:87-99

McLelland JA (2008) A systematic and taxonomic review of the family Pseudotanaidae (Crustacea: Peracarida: Tanaidacea) based primarily on morphometric cladistic analyses. Dissertation, University Of Southern Mississippi

Meißner K, Brenke N, Svavarsson J (2014) Benthic habitats around Iceland investigated during the IceAGE expeditions. Pol Polar Res 35:179-204

Mikkelsen NT, Todt C (2014) Diversity of Caudofoveata (Mollusca) around Iceland and description of Psilodens Balduri sp. n. Pol Polar Res 35:279-290. https://doi.org/10.2478/Popore-2014-0014

Ostmann A, Schnurr S, Martínez AP (2014) Marine environment around Iceland: hydrography, sediments and first predictive models of icelandic deep-sea sediment1039 characteristics. Pol Polar Res 35: 151-176. https://doi.org/10.2478/Popore-2014-0021

Pabis K, Jóźwiak P, Lorz AN, Schnabel K, Błażewicz-Paszkowycz M (2015) First insights into the deep-sea tanaidacean fauna of the RossSea-species richness and composition across the shelf break, slopeand abyss. Polar Biol 38:1429-1437

Perkins H, Hopkins TS, Malmberg SA, Poulain PM, Warn-Varnas A (1998) Oceanographic conditions east of Iceland. J Geophys Res 103:21531-21542
Riehl T, Brenke N, Brix S, Driskell A, Kaiser S, Brandt A (2014) Field and laboratory methods for DNA studies on deep-sea isopod crustaceans. Pol Polar Res 35:205-226

Sars GO (1869) Undersøgelser over Christianiafjordens Dybvandsfauna. Nyt Mag Naturv 16:305-362

Sars GO (1882) Revision af gruppen Chelifera med charakteristik af nye herhen hørende arter og slaegter. Archiv For Matematik Og Naturvidenskab 7:1-54

Sars GO (1896) An account of the Crustacea of Norway with short descriptions and figures of all the species. Isopoda. Bergen Museum 2:1-270

Schnurr S, Malyutina MS (2014) Two new species of the genus Eurycope (Isopoda, Munnopsidae) from Icelandic waters. Pol Polar Res 35: 361-388

Schnurr S, Brandt A, Brix S, Fiorentino D, Malyutina M, Svavarsson J (2014) Composition and distribution of selected munnopsid genera (Crustacea, Isopoda, Asellota) in Icelandic waters. Deep Sea Res I $84: 142-155$

Sieg J (1976) Zum Natürlichen system Der Dikonophora Lang (Crustacea, Tanaidacea). Zool Syst Evol 14:177-198

Sieg J (1977) Taxonomische monographie der familie Pseudotanaidae (Crustacea, Tanaidacea). Mitteilungen aus dem zoologischen museum in Berlin 53:1-109

Stephensen K (1937) Marine Isopoda and Tanaidacea. In Munksgaard E (Ed) The zoology of Iceland Vol. III, Kopenhagen, Reykjavik, pp 125

Todt C, Kocot KM (2014) New records for the solenogaster Proneomenia sluiteri (Mollusca) from icelandic waters and description of Proneomenia custodiens sp. n. Pol Polar Res 35:291-310 